\title{
Molecular Imaging of GLUT1 and GLUT5 in Breast Cancer: A Multitracer Positron Emission Tomography Imaging Study in Mice ${ }^{\mathbf{S}}$
}

\author{
Melinda Wuest, Ingrit Hamann, Vincent Bouvet, Darryl Glubrecht, Alison Marshall, \\ Brendan Trayner, Olivier-Mohamad Soueidan, Daniel Krys, Michael Wagner, \\ Chris Cheeseman, Frederick West, and Frank Wuest \\ Departments of Oncology and Cross Cancer Institute (M.Wu., I.H., V.B., D.G., A.M., D.K., M.Wa., F.Wu.), Chemistry (O.-M.S., \\ F.We.), and Physiology (B.T., O.-M.S., C.C.), University of Alberta, Edmonton, Alberta, Canada
}

Received July 18, 2017; accepted November 13, 2017

\begin{abstract}
Use of $\left[{ }^{18} \mathrm{~F}\right] \mathrm{FDG}$-positron emission tomography (PET) in clinical breast cancer $(\mathrm{BC})$ imaging is limited mainly by insufficient expression levels of facilitative glucose transporter (GLUT)1 in up to $50 \%$ of all patients. Fructose-specific facilitative hexose transporter GLUT5 represents an alternative biomarker for PET imaging of hexose metabolism in BC. The goal of the present study was to compare the uptake characteristics of selected hexose-based PET radiotracers in murine $\mathrm{BC}$ model EMT6. Uptake of 1-deoxy-1$\left[{ }^{18} \mathrm{~F} f\right.$ fluoro-D-fructose (1- $\left[{ }^{18} \mathrm{~F}\right.$ FDF), 6-deoxy-6- $\left[{ }^{18} \mathrm{~F}\right]$ fluoro-D-fructose (6- $\left.\left[{ }^{18} \mathrm{~F}\right] \mathrm{FDF}\right), \quad 1$-deoxy-1- $\left[{ }^{18} \mathrm{~F}\right]$ fluoro-2,5-anhydro-mannitol $\left(1-\left[{ }^{18} \mathrm{~F}\right]\right.$ FDAM), 2-deoxy-2- $\left[{ }^{18} \mathrm{~F}\right]$ fluoro-D-glucose $\left(2-\left[{ }^{18} \mathrm{~F}\right] \mathrm{FDG}\right)$, and 6-deoxy-6- $\left[{ }^{18} \mathrm{~F}\right]$ fluoro-D-glucose $\left(6-\left[{ }^{18} \mathrm{~F}\right] \mathrm{FDG}\right)$ was studied in EMT6 cells, tumors, and muscle and correlated to GLUT1 and GLUT5 expression levels. Fructose-derivative $\left.6-{ }^{18} \mathrm{~F}\right] \mathrm{FDF}$ revealed greater tumor uptake than did structural analog $1-\left[{ }^{18} \mathrm{~F}\right] \mathrm{FDF}$, whereas $1-\left[{ }^{18} \mathrm{~F}\right] \mathrm{FDAM}$ with locked anomeric configuration showed similar low tumor uptake to that of $1-\left[{ }^{18} \mathrm{~F}\right] \mathrm{FDF}$. Glucose-derivative
\end{abstract}

$6-\left[{ }^{18} \mathrm{~F}\right] \mathrm{FDG}$ reached maximum tumor uptake at 20 minutes, with no further accumulation over time. Uptake of $2-\left[{ }^{18} \mathrm{~F}\right] \mathrm{FDG}$ was greatest and continuously increasing owing to metabolic trapping through phosphorylation by hexokinase II. In EMT6 tumors, GLUT5 mRNA expression was 20,000-fold lower compared with GLUT1. Whereas the latter was much greater in tumor than in muscle tissue (GLUT1 50:1), the opposite was found for GLUT5 mRNA expression (GLUT5 1:6). GLUT5 protein levels were higher in tumor versus muscle tissue as determined by Western blot and immunohistochemistry. Our data suggest that tumor uptake of fructose metabolism-targeting radiotracers $1-\left[{ }^{18} \mathrm{~F}\right]$ FDF, $6-\left[{ }^{18} \mathrm{~F}\right] \mathrm{FDF}$, and $1-\left[{ }^{18} \mathrm{~F}\right] \mathrm{FDAM}$ does not correlate with GLUT5 mRNA levels but is linked to GLUT5 protein levels. In conclusion, our results highlight the importance of detailed biochemical studies on GLUT protein expression levels in combination with PET imaging studies for functional characterization of GLUTs in BC.

\section{Introduction}

Breast cancer (BC) is the most common malignancy in females (Siegel et al., 2017). Specific biomarkers have become

The authors thank Dr. John Wilson, David Clendening, and Blake Lazurko from the Edmonton PET Center for ${ }^{18} \mathrm{~F}$ production and excellent technical support; Dan McGinn from the Vivarium of the Cross Cancer Institute for supporting the animal work; Dr. Hans-Soenke Jans from the Division of Medical Physics for technical support of the animal imaging facility (Department of Oncology, University of Alberta); and Cody Bergman for his help with precursor purifications. Ingrit Hamann thanks the Alberta Cancer Foundation (ACF) for a postdoctoral fellowship award.The authors also gratefully acknowledge the Dianne and Irving Kipnes Foundation, the Canadian Institute of Health Research (CIHR), the Canadian Breast Cancer Foundation (CBCF), the Collaborative Health Research Program (CHRP), and the National Science and Engineering Research Council of Canada (NSERC) for supporting this work.

https://doi.org/10.1124/mol.117.110007.

S This article has supplemental material available at molpharm. aspetjournals.org. important for patient selection and personalized targeted treatment decisions based on precision medicine concept (Jameson and Longo, 2015). In addition to tissue samplingbased biomarker assays, functional molecular imaging with positron emission tomography (PET) can also serve as a biomarker for disease diagnosis and prognosis and for guiding treatment decisions. The important role of PET imaging for $\mathrm{BC}$ management has been summarized in recent reviews (Oude-Munnink et al., 2009; Lebron et al., 2015; Kurihara et al., 2016; Ulaner et al., 2016; Chudgar and Mankoff, 2017).

Among the available PET agents, 2-deoxy-2- $\left[{ }^{18} \mathrm{~F}\right]$ fluoro-Dglucose (2- $\left.\left[{ }^{18} \mathrm{~F}\right] \mathrm{FDG}\right)$ is the only Food and Drug Administrationapproved radiotracer for monitoring $\mathrm{BC}$ treatment in primary and metastatic disease (Humbert et al., 2015). $\left[{ }^{18} \mathrm{~F}\right]$ FDG-PET has also demonstrated variable sensitivity in $\mathrm{BC}$ detection, depending on histologic tumor type. Regulatory bodies and numerous

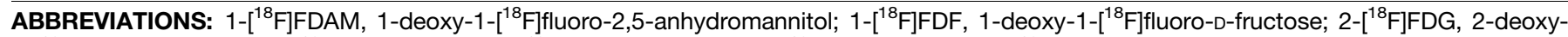
$6-\left[{ }^{18} \mathrm{~F}\right]$ fluoro-D-glucose; 6- $\left[{ }^{18} \mathrm{~F}\right] \mathrm{FDF}, 6$-deoxy-6- $\left[{ }^{18} \mathrm{~F}\right]$ fluoro-D-fructose; $6-\left[{ }^{18} \mathrm{~F}\right] \mathrm{FDG}, 6$-deoxy-6- $\left[{ }^{18} \mathrm{~F}\right]$ fluoro-D-glucose; ANOVA, analysis of variance; BC, breast cancer; GLUT1, facilitative glucose transporter 1; GLUT2, facilitative glucose transporter 2; GLUT5, facilitative glucose transporter 5; MSNBA, N-(4-methanesulfonyl-2-nitrophenyl)-2H-1,3-benzodioxol-5-amine; NMR, nuclear magnetic resonance; NSNBA, N-(4-methanesulfonyl-2nitrophenyl)-2H-1,3-benzodioxol-5-amine; PCR, polymerase chain reaction; PET, positron emission tomography; ROI, region of interest; SUV, standardized uptake values; TBST, Tween-20. 
studies do not recommend $\left[{ }^{18} \mathrm{~F}\right] \mathrm{FDG}$-PET as a standard procedure for $\mathrm{BC}$ diagnosis and disease staging in primary invasive $\mathrm{BC}$ (Avril et al., 2001; Oude-Munnink et al., 2009; Lebron et al., 2015).

Increased uptake of $2-\left[{ }^{18} \mathrm{~F}\right] \mathrm{FDG}$ is based mainly on overexpression of facilitative hexose transporter GLUT1 in cancer cells (Yamamoto et al., 1990; Brown et al., 1996; Avril et al., 2001; Jadvar et al., 2009); however, variable sensitivity and specificity of $\left[{ }^{18} \mathrm{~F}\right]$ FDG-PET in certain cancers, including BC, have limited its usefulness in both primary and metastatic disease (Gallamini et al., 2014; Kitajima and Miyoshi, 2016). About 28\%-47\% of BC patients are GLUT1-negative or do not show elevated GLUT1 expression sufficient for $2-\left[{ }^{18} \mathrm{~F}\right] \mathrm{FDG}$ uptake (primary lesions with $\sim 50 \%$ metastatic disease, Kuo et al., 2006; primary lesions, Laudański et al., 2004; primary lesions with negative lymph nodes, Ravazoula et al., 2003; primary lesions with higher grade, Younes et al., 1995). Functional changes in $2-\left[{ }^{18} \mathrm{~F}\right] \mathrm{FDG}$ uptake do not correlate with changes in GLUT1 expression in primary BC (Avril et al., 2001). They rather occur as the result of a complex interaction between cellular energy demand and tumor microenvironment. Therefore, alternative biomarkers of tumor metabolism are of interest for BC. The class II hexose transporter GLUT5, responsible for transport of fructose across cell membranes, represents such an alternative biomarker.

GLUT2 and GLUT5 are primarily responsible for fructose transport across cell membranes (Macheda et al., 2005; Manolescu et al., 2007). They significantly differ in their affinity for fructose (GLUT5 $(6 \mathrm{mmol} /$ liter) $>>$ GLUT2 (76 mmol/liter) (Barron et al., 2016). In 1996, GLUT5 was first proposed as a novel target for diagnosis and treatment of BC (Zamora-León et al., 1996), followed by confirmation of elevated GLUT5 protein expression in BC (Godoy et al., 2006), which has prompted development of various fluorescence-labeled and radiolabeled fructose derivatives targeting GLUT5 (Haradahira et al., 1995; Levi et al., 2007; Trayner et al., 2009; Wuest et al., 2011; Tanasova et al., 2013). Fructose derivative 1-deoxy-1- $\left[{ }^{18} \mathrm{~F}\right]$ fluoro-D-fructose $\left(1-\left[{ }^{18} \mathrm{~F}\right]\right.$ FDF) was the first PET radiotracer studied in a fibrosarcoma tumor model (Haradahira et al., 1995), but no GLUT5 levels were analyzed. Two fluorescent fructose derivatives (1-NBDF and 1-Cy5.5-DF) showed good uptake in various BC cells and 1-NBDF uptake corresponded with fructose uptake (Levi et al., 2007).

Our group developed fructose derivative 6-deoxy-6-fluoro-Dfructose (6-FDF), which accumulated in GLUT5-expressing BC cells (Trayner et al., 2009). Evaluation of ${ }^{18} \mathrm{~F}$-labeled 6-FDF $\left(6-\left[{ }^{18} \mathrm{~F}\right] \mathrm{FDF}\right)$ demonstrated fructose-mediated uptake in different $\mathrm{BC}$ cells and tumors (Wuest et al., 2011). In contrast to $1-\left[{ }^{18} \mathrm{~F}\right] \mathrm{FDF}, 6-\left[{ }^{18} \mathrm{~F}\right] \mathrm{FDF}$ displayed efflux from BC cells, indicative of there being no intracellular metabolic trapping as confirmed by phosphorylation experiments with ketohexokinase and hexokinase II. $6-\left[{ }^{18} \mathrm{~F}\right] \mathrm{FDF}$ is a substrate of ketohexokinase but not of hexokinase II. Fluorescent 2,5-anhydro-D-mannitol derivative (NBDM) was tested for GLUT5 transport selectivity over GLUT2 in BC cells (Tanasova et al., 2013). In parallel, our group analyzed fluorinated 2,5-anhydro-D-mannitol derivative (1-FDAM), which possesses GLUT5-mediated uptake into BC cells (Soueidan et al., 2015). Recent analysis of GLUT5 mRNA in BC cells, including knockdown experiments of GLUT5 expression using RNA interference and immunocytochemistry, revealed that GLUT5 may not be the only transporter essential for fructose uptake in $\mathrm{BC}$ cells and tissue (Gowrishankar et al., 2011).

The goal of this study was to further analyze whether radiolabeled fructose analogs can be used as metabolic radiotracers for molecular imaging of GLUT5 in BC: 1) We studied tumor uptake of various ${ }^{18} \mathrm{~F}$-labeled fructose, 2,5-anhydro-D-mannitol, and glucose derivatives $\left(1-\left[{ }^{18} \mathrm{~F}\right] \mathrm{FDF}, 6-\left[{ }^{18} \mathrm{~F}\right] \mathrm{FDF}, 1-\left[{ }^{18} \mathrm{~F}\right] \mathrm{FDAM}\right.$, $2-\left[{ }^{18} \mathrm{~F}\right] \mathrm{FDG}$, and $\left.6-\left[{ }^{18} \mathrm{~F}\right] \mathrm{FDG}\right)$ in well characterized mammary tumor model EMT6 in vitro and in vivo and 2) correlated uptake of radiotracers with GLUT5 mRNA and protein expression levels in EMT6 cells, tumor and muscle tissue.

\section{Materials and Methods}

Chemical and Radiochemical Syntheses. Nonradioactive compounds for cellular inhibition experiments were prepared according to literature [1-FDF: Haradahira et al., 1995; 3-FDF, 6-FDF, and 1-FDAM: Wuest et al., 2011; Soueidan et al., 2015; 6-FDG: Neal et al., 2005). Radiotracer $2-\left[{ }^{18} \mathrm{~F}\right]$ FDG was prepared at the Edmonton PET Center of the Cross Cancer Institute using a GE TracerLab MX automated synthesis unit (GE Healthcare Canada Inc., Mississauga, Ontario, Canada). Synthesis of radiotracers 1-[ $\left[{ }^{18} \mathrm{~F}\right] \mathrm{FDAM}, 1-\left[{ }^{18} \mathrm{~F}\right]$ FDF, 6- $\left[{ }^{18} \mathrm{~F}\right] \mathrm{FDF}$, and $6-\left[{ }^{18} \mathrm{~F}\right] \mathrm{FDG}$ was carried out based on procedures reported in the literature (Haradahira et al., 1995; Neal et al., 2005; Niu et al., 2013; Bouvet et al., 2014).

GLUT5 inhibitor MSNBA ( $N$-(4-methanesulfonyl-2-nitrophenyl)2H-1,3-benzodioxol-5-amine) was synthesized as follows: 3,4-(methylenedioxy)aniline (1.37 g, $10 \mathrm{mmol}$ ) and 1-fluoro-4-methansulfonyl-2-nitrobenzene $(2.19 \mathrm{~g}, 10 \mathrm{mmol})$ were heated to reflux in water $(50 \mathrm{ml})$. After 40 minutes, $\mathrm{Na}_{2} \mathrm{CO}_{3}(1.8 \mathrm{~g})$ was carefully added, and the reaction mixture was cooled to room temperature. The crude product was filtered off, and the aqueous phase was extracted with ethyl acetate (EtOAc). The combined organic extracts including the crude product were dried over $\mathrm{Na}_{2} \mathrm{SO}_{4}$, and the solvent was removed in vacuo. The dark residue was purified using flash chromatography $\left(\mathrm{SiO}_{2}\right.$, EtOAc/hexane $1: 2 \rightarrow 2: 1$ ). The obtained red solid was recrystallized from EtOAc/EtOH/hexane to give an orange solid that was dried in vacuo. Yield was $64.7 \%$ (2.175 g, $6.47 \mathrm{mmol}$ ), $\mathrm{mp}>154^{\circ} \mathrm{C}$ (decomp.), highperformance-liquid chromatography: $>98 \%$ purity (@280 nm), $\mathrm{R}_{\mathrm{f}}$ (hexane/ethylacetate $1: 1)=0.36,{ }^{1} \mathrm{H}$ nuclear magnetic resonance $(\mathrm{NMR})\left(600.27 \mathrm{MHz},\left(\mathrm{CD}_{3}\right)_{2} \mathrm{~S}=\mathrm{O}\right): \delta 9.81(\mathrm{~s}, 1 \mathrm{H}), 8.54(\mathrm{~d}, J=2.3 \mathrm{~Hz}$, $1 \mathrm{H}), 7.86(\mathrm{dd}, J=1.9 \mathrm{~Hz}, J=9.0 \mathrm{~Hz}, 1 \mathrm{H}), 7.07(\mathrm{~d}, J=9.0 \mathrm{~Hz}, 1 \mathrm{H}), 7.01$ $(\mathrm{d}, J=9.0 \mathrm{~Hz}, 1 \mathrm{H}), 6.97(\mathrm{~d}, J=1.9 \mathrm{~Hz}), 6.84(\mathrm{dd}, J=1.9 \mathrm{~Hz}, J=7.9 \mathrm{~Hz}$, $1 \mathrm{H}), 6.02\left(\mathrm{~s}, 2 \mathrm{H}, \mathrm{CH}_{2}\right), 3.21\left(\mathrm{~s}, 3 \mathrm{H}, \mathrm{CH}_{3}\right) ;{ }^{13} \mathrm{C}$ NMR $(150.94 \mathrm{MHz}$, $\left(\mathrm{CD}_{3}\right)_{2} \mathrm{~S}=\mathrm{O}$ ): $\delta 148.1$ (C quart.),146.6 (C quart.), 146.1 (C quart.), 133.3 (C-H), 131.7 (C quart.), 131.0 (C quart.), 126.8 (C-H), 119.7 $(\mathrm{C}-\mathrm{H}), 117.3(\mathrm{C}-\mathrm{H}), 108.8(\mathrm{C}-\mathrm{H}), 107.6(\mathrm{CH}), 101.7\left(\mathrm{CH}_{2}\right), 43.7\left(\mathrm{CH}_{3}\right)$; $\operatorname{ESI~MS~}\left(\mathrm{CH}_{3} \mathrm{CN},+\right): m / z 337.0\left([\mathrm{M}+\mathrm{H}]^{+}, 100 \%\right) ; \operatorname{ESI~MS}\left(\mathrm{CH}_{3} \mathrm{CN},-\right)$ : $\mathrm{m} / z 335.0\left([\mathrm{M}-\mathrm{H}]^{+}, 100 \%\right)$; UV/Vis (acetonitrile): $\lambda_{\max }(\varepsilon): 410 \mathrm{~nm}(43601$ $\left.\mathrm{mol}^{-1} \mathrm{~cm}^{-1}\right), 280 \mathrm{~nm}\left(11,1401 \mathrm{~mol}^{-1} \mathrm{~cm}^{-1}\right)$. The ${ }^{1} \mathrm{H}$ NMR spectrum of the GLUT-5 inhibitor confirmed the commercially available compound (Enamine Ltd, Kiev, Ukraine) as reported by George Thompson et al. (2016). MSNBA was soluble at $150 \mu \mathrm{mol} /$ liters in $1 \%$ dimethylsulfoxide (DMSO)/ $\mathrm{H}_{2} \mathrm{O}$.

Cell Culture. Murine mammary gland tumor cells EMT6 (ATTC CRL-2755) and human BC cells MDA-MB231 (ATCC HTB-26) were grown in a $\mathrm{CO}_{2}$ incubator at $37^{\circ} \mathrm{C}$, in Gibco DMEM/F-12 supplemented with $10 \%$ fetal bovine serum (GIBCO 12483; Gibco, Gaithersburg, $\mathrm{MD})$ and $1 \%$ penicillin/streptomycin and split every 2 to 3 days.

mRNA Expression of GLUT-1 and GLUT-5. Total RNA was isolated from EMT6 cells, EMT6 tumor tissue, and mouse muscle tissue by using the TRIzol Plus RNA Purification Kit (Applied Biosystems, Life Technologies, Burlington, ON, Canada). EMT6 cells were harvested using TRIzol reagent; tissues were excised from euthanized mice and immediately frozen in liquid nitrogen. Samples were stored at $-80^{\circ} \mathrm{C}$. 
Later, tissues were pulverized using a mortar and pestle containing liquid nitrogen and resuspended in the provided lysis buffer of the purification kit. RNA from cells and tissues was purified according to the manufacturer's instructions and stored at $-80^{\circ} \mathrm{C}$. RNA was reverse-transcribed into cDNA using the high-capacity cDNA reverse transcription kit (Applied Biosystems, Life Technologies) according to the manufacturer's instructions. Quantitation of GLUT1, GLUT2, GLUT5, and 18 second RNA mRNA levels were performed by realtime polymerase chain reaction (PCR) using specific TaqMan gene expression assays (Applied Biosystems, Life Technologies) using probes 5'-labeled with 6-FAM and 3' with MGBNFQ (Minor groove binder/non-fluorescent quencher). The following TaqMan gene expression assays were used: GLUT1 (Mm00441480_m1), GLUT2 (Mm00446229_m1), GLUT5 (Mm00600311_m1), and, as an internal control, 18-second RNA (Mm039288990_g1).

Cycling conditions were the manufacturer's recommended default values (one cycle of 2 minutes at $50^{\circ} \mathrm{C}$ and 10 minutes at $95^{\circ} \mathrm{C}$, then 40 cycles of 15 seconds at $95^{\circ} \mathrm{C}$ and 1 minute at $60^{\circ} \mathrm{C}$ ) and performed on a CFX Connect Real-Time PCR Detection System (BioRad, Mississauga, ON, Canada).

Real-time PCR data were analyzed using relative gene expression as described already (Livak and Schmittgen 2001; Pfaffl 2001). For each sample, a threshold cycle $\left(C_{\mathrm{T}}\right)$ was calculated based on the time (measured by the number of PCR cycles) at which the reporter fluorescence emission increased beyond a threshold level based on the background fluorescence of the system. Triplicate measurements were done for each sample in three independent experiments. Results were expressed using the comparative $C_{\mathrm{T}}$ method with $18 \mathrm{~s}$ RNA as the housekeeping gene, which was investigated with the genes of interest to rule out variations that resulted from pipetting, cDNA synthesis, PCR reaction, and so forth; $C_{\mathrm{T}}$ values for the genes of interest were normalized to the $C_{\mathrm{T}}$ values of $18 \mathrm{~s}$ RNA. Relative differences in the expression level of the two genes of interest were calculated in the following manner:

$$
\begin{aligned}
R= & \left(2^{\left(C_{\mathrm{T}} \mathrm{GLUT} 1-C_{\mathrm{T}} \mathrm{GLUT} 5\right)}\right) / \\
& \left(2^{\left(C_{\mathrm{T}} 18 \mathrm{~s} \text { RNA for GLUT1 }-C_{\mathrm{T}} 18 \mathrm{~s} \text { RNA for GLUT5 }\right)}\right)
\end{aligned}
$$

or

$$
\begin{aligned}
& R=\left(2^{\left(C_{\mathrm{T}} \text { GLUT tumor }-C_{\mathrm{T}} \text { GLUT muscle }\right)}\right) / \\
& \left(2^{\left(C_{\mathrm{T}} 18 \mathrm{~s} \text { RNA for GLUT tumor }-C_{\mathrm{T}} 18 \mathrm{~s} \text { RNA for GLUTmuscle }\right)}\right)
\end{aligned}
$$

GLUT5 Protein Expression. Western blots for detection of GLUT5 protein levels were carried out with tumor and muscle tissues of EMT6 tumor-bearing BALB/c mice. Tissues were excised from euthanized mice and immediately frozen in liquid nitrogen. Samples were stored at $-80^{\circ} \mathrm{C}$. Later, tissues were pulverized using a mortar and pestle, containing liquid nitrogen and re-suspended in lysis buffer (50 mM Tris, $150 \mathrm{mM} \mathrm{NaCl}, 0.1 \%$ SDS, $0.5 \%$ sodium deoxycholate, $0.5 \%$ Triton $\mathrm{X}$ ). After cell lysis on ice for 30 minutes, extracts were sonicated (10\% amplitude, 10 seconds) on ice and centrifuged at $13,500 \mathrm{~g}$ for 10 minutes at $4^{\circ} \mathrm{C}$ to remove debris. Protein determination in supernatants was conducted using a bicinchoninic acid-based protein assay (Pierce/Thermo Scientific, Rockford, IL). Aliquots of the supernatants were mixed with $1 / 4$ volume of $4 \times$ Laemmli buffer [250 mM Tris $/ \mathrm{HCl}, 8 \%$ (w/v) SDS, $40 \%$ glycerol, $200 \mathrm{mM}$ dithiothreitol, and $0.04 \%(\mathrm{w} / \mathrm{v})$ bromophenol blue, $\mathrm{pH} 6.8$ ] and heated for 5 minutes at $95^{\circ} \mathrm{C}$. The protein extracts were applied to SDS-PAGE gels and separated by electrophoresis. Proteins were transferred to nitrocellulose membranes by electroblotting and blocked for 1 hour at room temperature in $5 \%(\mathrm{w} / \mathrm{v})$ nonfat dry milk in Tris-buffered saline containing $0.05 \%(\mathrm{v} / \mathrm{v})$ of Tween-20 (TBST). Membranes were incubated overnight at $4^{\circ} \mathrm{C}$ with the following primary antibodies: mouse monoclonal anti-GLUT5 IgG1 (clone E2, sc-271055, 1:500; Santa Cruz Biotechnology, Dallas, TX) and mouse anti- $\alpha$-tubulin (12G10, 1:50,000; Developmental Studies Hybridoma Bank), followed by incubation for 1 hour at room temperature with a peroxidaseconjugated anti-mouse IgG1 secondary antibody (sc-2060; Santa Cruz Biotechnology) in 1:5000 dilution and 100,000 dilution, respectively.

After incubation with secondary antibodies, membranes were washed in TBST and, depending on protein levels, incubated with Thermo Scientific SuperSignal West Pico Chemiluminescent Substrate (Thermo Scientific) or Clarity ECL Western blotting substrate (BioRad). Luminescence signals were captured, using Fuji medical X-ray films (Fujifilm Canada, Mississauga, Ontario, Canada). Films were scanned, and analysis was done using the ImageJ program. Density of each band was determined, and individual lane backgrounds were subtracted. Values for GLUT5 protein were divided by values for the housekeeping protein $\alpha$-tubulin. Received values for each individual muscle were set at $100 \%$ and compared with the individual value of the respective tumor tissue (band density Glut5, density lane background)/(band density $\alpha$-tubulin, density lane background), respectively.

In Vitro Inhibition of $6-\left[{ }^{18}\right.$ F]FDF and $2-\left[{ }^{18}\right.$ F $]$ FDG Cell Uptake. To estimate the affinity of nonradiolabeled fructose derivatives (1-, 3- and 6-FDF), as well as the 2,5-anhydro-D-mannitol 1-FDAM for fructose-mediated transport in comparison with that of D-fructose itself, ranges for half-maximum inhibition coefficient $\left(\mathrm{IC}_{50}\right)$ values of both compounds were estimated.

EMT6 cells were incubated with glucose-free Krebs-Ringer buffer containing $6-\left[{ }^{18} \mathrm{~F}\right] \mathrm{FDF}$ and different concentrations of either 1-FDF, 6-FDF, 3-FDF, 1-FDAM $\left(10^{-8}-10^{-3}-3 \times 10^{-2} \mathrm{M}\right)$ or fructose $\left(10^{-5}-1\right.$ M) and no compound at all for comparison (=100\% uptake). After 60 minutes, cells were rinsed with ice-cold Krebs-Ringer solution, lysed, and counted in a $\gamma$-counter as described as follows. Increasing concentrations of glucose were analyzed on $6-\left[{ }^{18} \mathrm{~F}\right] \mathrm{FDF}$ uptake (60 minutes' incubation) in MDA-MB 231 cells, increasing the concentrations of fructose as well as cytochalasin B $\left(10^{-7}-3 \times 10^{-5}\right.$ M) against $2-\left[{ }^{18} \mathrm{~F}\right] \mathrm{FDG}$ uptake. Novel selective GLUT5 inhibitor MSNBA (100-300 $\mu \mathrm{M}$ in Krebs buffer 1\% DMSO) was analyzed on 6- $\left[{ }^{18} \mathrm{~F}\right] \mathrm{FDF}$ and $2-\left[{ }^{18} \mathrm{~F}\right] \mathrm{FDG}$ uptake into murine EMT6 cells.

In Vitro Cell Uptake of ${ }^{18}$ F-Labeled Radiotracers. For radiotracer uptake studies, cells were grown to confluence in 12 -well plates using in Gibco DMEM/F-12 medium containing 10\% fetal bovine serum (GIBCO, 12483) and 1\% penicillin/streptomycin). One hour before the experiment, the media were removed, and the cells were washed twice with phosphate-buffered saline solution (PBS). Next, glucose-free Krebs-Ringer solution $(120 \mathrm{mM} \mathrm{NaCl}, 4 \mathrm{mM} \mathrm{KCl}, 1.2 \mathrm{mM}$

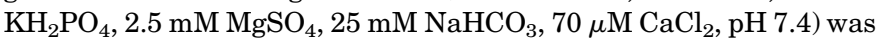
added to the cells. Three hundred microliters of Krebs-Ringer (with or without $5 \mathrm{mM}$ glucose or $30 \mathrm{mM}$ fructose) solution with $0.1-0.5 \mathrm{MBq}$ ${ }^{18} \mathrm{~F}$-labeled radiotracer was added to each well, and the plates were incubated at $37^{\circ} \mathrm{C}$ for specific periods $(5,10,15,30,45$, and 60 minutes). Radiotracer uptake was stopped with $1 \mathrm{ml}$ of ice-cold PBS, and the cells were washed twice with PBS and lysed in $0.4 \mathrm{ml}$ radioimmunoprecipitation assay buffer (RIPA buffer). Radioactivity in the cell lysates was determined as counts per minute [CPM] using a WIZARD2 automatic $\gamma$-counter (Perkin Elmer, Waltham, MA) and converted to the radioactivity dose SI unit Bequerel [Bq]. Total protein concentration in the samples was determined by the bicinchoninic acid method (BCA 23227; Pierce, Thermo Scientific) using bovine serum albumin as protein standard. Data were calculated as percent of measured radioactivity per milligram of protein (\% radioactivity/mg of protein). Cell uptake of $6-\left[{ }^{18} \mathrm{~F}\right] \mathrm{FDF}$ and $2-\left[{ }^{18} \mathrm{~F}\right] \mathrm{FDG}$ after 60 minutes of incubation time was compared in murine EMT6 versus human MDA-MB231 BC cells. Graphs were constructed using GraphPad Prism 5.0 (GraphPad Software, San Diego, CA). Statistical differences were tested by unpaired Student's $t$ test and were considered significant for $P<0.05$. Data were statistically analyzed with oneway analysis of variance (ANOVA) plus Bonferroni post-test and considered significant for $P<0.05$.

Animal Model. All animal experiments were carried out in accordance with guidelines of the Canadian Council on Animal Care and approved by the local animal care committee of the Cross Cancer Institute. 
Murine EMT6 cells $\left(1 \times 10^{6}\right.$ cells in $100 \mu$ l of PBS $)$ were injected into the upper left shoulder of 4- to 6-month-old female BALB/c mice (20-24 g; Charles River, Saint-Constant, QC, Canada). The EMT6 tumor-bearing mice were imaged after allowing 7-11 days of tumor growth, reaching sizes of $\sim 300-400 \mathrm{~mm}^{3}$. The mice were not fasted before imaging experiments.

Immunohistochemistry GLUT5. Excised tissues from euthanized mice were fixed in neutral-buffered $10 \%$ formalin overnight and embedded in paraffin. Sections of $4-\mu \mathrm{m}$ thickness were dried in an oven at $60^{\circ} \mathrm{C}$ for 1 hour. Sections were rehydrated by placing the slides in three changes of xylene for 10 minutes each and then in graded ethanol from $100 \%$ to $50 \%$, followed by water and TBS. Slides were microwaved in a pressure cooker for 6 minutes in citraconic anhydride $(0.05 \%$ in water, $\mathrm{pH} 7.4)$ for antigen retrieval. Slides were blocked with $0.5 \%$ fish gelatin in TBS with $0.05 \%$ TBST for 30 minutes and incubated with mouse monoclonal anti-GLUT5 antibody (clone E2, sc-271055, 1:50; Santa Cruz Biotechnology) in a humidity chamber overnight at $4^{\circ} \mathrm{C}$. After incubation in $3 \% \mathrm{H}_{2} \mathrm{O}_{2}$ in water for 15 minutes, slides were incubated with DakoCytomation Envision+ anti-mouse labeled polymer HRP (DakoCytomation, Glostrup, Denmark) for 1 hour, developed using Dako Liquid $\mathrm{DAB}+$ substrate chromagen system and $1 \%$ copper sulfate and counterstained with hematoxylin.

Slides were dehydrated by reversing rehydration procedure and coverslipped. Negative control was provided by omitting the GLUT5 primary antibody, whereas positive control was provided by examining sections of murine small intestine, a tissue known to express GLUT5.

In Vivo PET Experiments. EMT6 tumor-bearing BALB/c mice were anesthetized with isoflurane in $40 \%$ oxygen $/ 60 \%$ nitrogen (gas flow, $1 \mathrm{l} / \mathrm{min}$ ), and body temperature was kept constant at $37^{\circ} \mathrm{C}$ for the entire experiment. Mice were positioned and immobilized in the prone position into the center of the field of view of an INVEON PET scanner (Siemens Preclinical Solutions, Knoxville, TN). A transmission scan for attenuation correction was not acquired. The amount of radioactivity $[\mathrm{Bq}]$ present in the injection solution in a $0.5-\mathrm{ml}$ syringe was determined with a dose calibrator (Atomlab 300; Biodex Medical Systems, Suffolk, NY). After emission scan was started, radioactivity was injected with a delay of approximately 15 seconds. Data acquisition continued for 120 minutes in $3 \mathrm{D}$ list mode. Four to eight Mega Bq of ${ }^{18} \mathrm{~F}$-labeled radiotracer in $100-150 \mu \mathrm{l}$ of saline was injected through a tail-vein catheter. The list mode data were sorted into sinograms with 59 time frames $(10 \times 2,8 \times 5,6 \times 10,6 \times 20,8 \times 60,10 \times 120,10 \times$ 300 seconds). The frames were reconstructed using the Ordered Subset Expectation Maximization (OSEM) or maximum a posteriori reconstruction modes. No correction for partial-volume effects was performed. The image files were further processed using the ROVER v2.0.51 software (ABX GmbH, Radeberg, Germany).

Masks defining 3D regions of interest (ROI) were set, and the ROIs were defined by thresholding. ROIs covered all visible tumor mass of the subcutaneous tumors, and the thresholds were defined by $50 \%$ of the maximum radioactivity uptake level for each EMT6 tumor in each animal. Mean standardized uptake values $\left[\mathrm{SUV}_{\text {mean }}=(\right.$ activity $[\mathrm{Bq}] / \mathrm{ml}$ tissue)/(injected activity [Bq]/body weight), $\mathrm{ml} / \mathrm{kg}$ ] were calculated for each ROI. Time-activity curves (TAC) were generated from the dynamic scans. All semiquantified PET data are presented as means \pm S.E.M. Time-activity curves were constructed using GraphPad Prism 5.0 (GraphPad Software). Statistical differences were tested by paired (comparing tumor and muscle uptake in the same mice), and unpaired Student's $t$ test and were considered significant for $P<0.05$. Tumor-tomuscle ratios were statistically analyzed with one-way ANOVA plus Bonferroni post-test and considered significant for $P<0.05$.

\section{Results}

Figure 1 displays the structures $\left({ }^{18} \mathrm{~F}\right.$-labeled fructose, glucose, and 2,5-anhydro-D-mannitol derivatives) used for the present study. All radiotracers were obtained at high

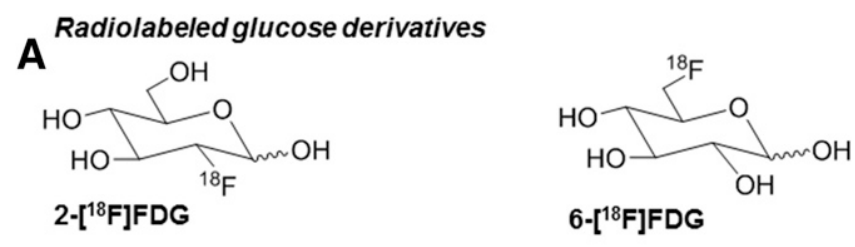

Radiolabeled fructose derivatives<smiles>OC[C@H]1OC(O)(C[18F])C(O)[C@H]1O</smiles><smiles>OCC1(O)O[C@H](C[18F])[C@@H](O)C1O</smiles>

Radiolabeled mannitol derivative

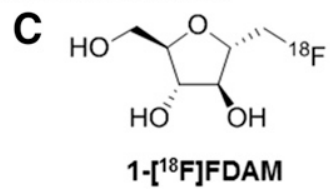

Fig. 1. Chemical structures of ${ }^{18} \mathrm{~F}$-labeled glucose (A), fructose (B), and 2,5-anhydro-D-mannitol (C) derivatives.

radiochemical purity ( $>95 \%$ ) and high-volume activities suitable for all subsequent in vitro and in vivo experiments.

Cellular Uptake Studies. Two different cellular uptake studies were carried out using murine mammary gland tumor cell line EMT6. The first set of experiments involved inhibition studies of radiotracer $6-\left[{ }^{18} \mathrm{~F}\right] \mathrm{FDF}$ in the presence of D-fructose; fructose derivatives 1-FDF, 3-FDF, and 6-FDF; and 2,5anhydro-D-mannitol derivative 1-FDAM according to a procedure developed by our research group (Wuest et al., 2011). Uptake of radiotracer $6-\left[{ }^{18} \mathrm{~F}\right] \mathrm{FDF}$ into EMT6 cells was competitively inhibited using increasing concentrations of nonradiolabeled compounds. Based on the inherent limitations of the assay regarding to the high concentrations of nonradiolabeled compounds $(>100 \mathrm{mM})$, it was possible to estimate only the $\mathrm{IC}_{50}$ ranges (Fig. $2 \mathrm{~A}$ ).

As measured, the estimated $\mathrm{IC}_{50}$ values for 1-FDF, 3-FDF, and 1-FDAM should be in a range similar to that for 6-FDF. Therefore, all analyzed fructose derivatives may more potent than fructose itself; however, this was measured competing against $6-\left[{ }^{18} \mathrm{~F}\right] \mathrm{FDF}$ and not radiolabeled fructose. $\mathrm{IC}_{50}$ values for the inhibition of $6-\left[{ }^{18} \mathrm{~F}\right] \mathrm{FDF}$ uptake in EMT6 cells have been previously reported for 6-FDF $(19 \mathrm{mM})$ and D-fructose (322 mM) (Wuest et al., 2011). The results were reproduced in the present study.

A second experimental setup analyzed the direct uptake pattern of ${ }^{18} \mathrm{~F}$-labeled fructose and 2,5-andydromannitol derivatives $1-\left[{ }^{18} \mathrm{~F}\right] \mathrm{FDF}, 6-\left[{ }^{18} \mathrm{~F}\right] \mathrm{FDF}$, and $1-\left[{ }^{18} \mathrm{~F}\right] \mathrm{FDAM}$ into EMT6 cells in comparison with glucose derivatives $2-\left[{ }^{18} \mathrm{~F}\right]$ FDG and $6-\left[{ }^{18} \mathrm{~F}\right]$ FDG (Fig. 2B). The $6-\left[{ }^{18} \mathrm{~F}\right] \mathrm{FDF}$ reached a cellular uptake level of $26 \% \pm 3 \%$ radioactivity/mg of protein $(n=9)$ after 60 minutes, whereas uptake values for $1-\left[{ }^{18} \mathrm{~F}\right]$ FDF and $1-\left[{ }^{18} \mathrm{~F}\right] \mathrm{FDAM}$ were significantly lower $(5.5 \pm 0.5(n=$ $9 ; P<0.001)$ and $3 \% \pm 0.1 \%$ radioactivity $/ \mathrm{mg}$ of protein $(n=3$; $P<0.001)$ ). Glucose derivatives 2 - $\left[{ }^{18} \mathrm{~F}\right] \mathrm{FDG}$ displayed high uptake levels of $622 \% \pm 25 \%$ radioactivity/mg protein $(n=3)$, whereas $6-\left[{ }^{18} \mathrm{~F}\right] \mathrm{FDG}$ showed only very low cellular uptake of $2.2 \% \pm 0.3 \%$ radioactivity/mg protein $(n=3)$.

The observed differences in cellular uptake levels demonstrate the importance of stereochemistry and substitution 
Inhibiting 6-[ $\left.{ }^{18} \mathrm{~F}\right] \mathrm{FDF}$ transport in murine A EMT6 cells

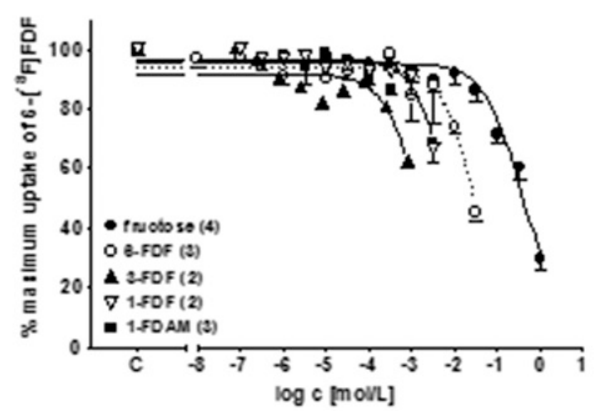

Inhibiting 2-[18F]FDG transport in murine c and human breast cancercell lines

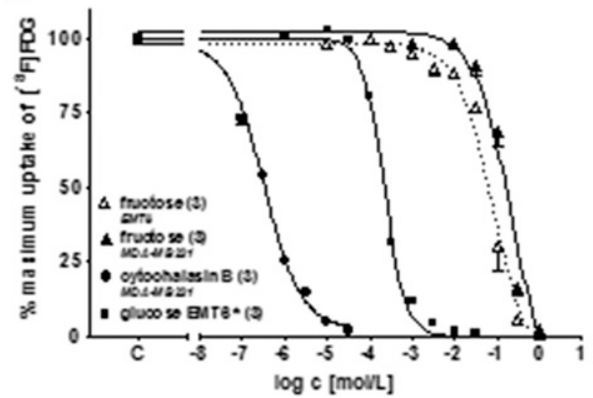

Cell uptake into murine and human breast cancer cell lines

E

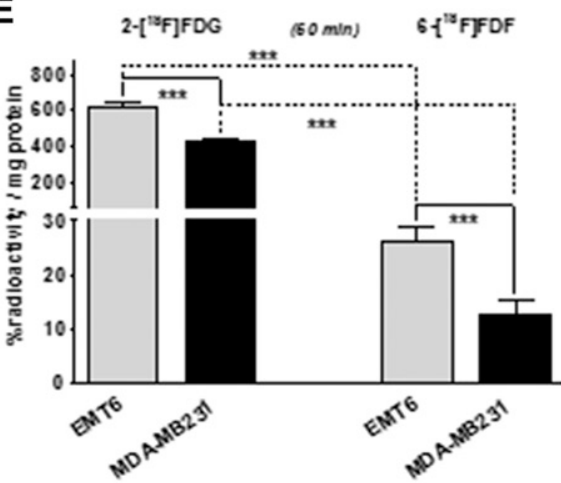

Effect of GLUT5 blocker MSNBA on 2 -[ $\left.{ }^{18} \mathrm{~F}\right]$ FDG transport in murine EMT6 cells

G

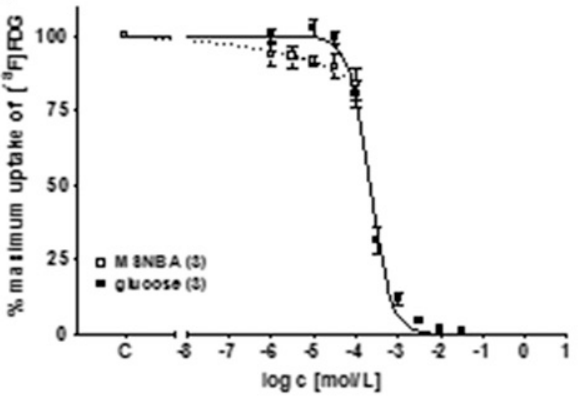

Cell uptake of fructose and glucose

B derivatives into murine EMT6 cells

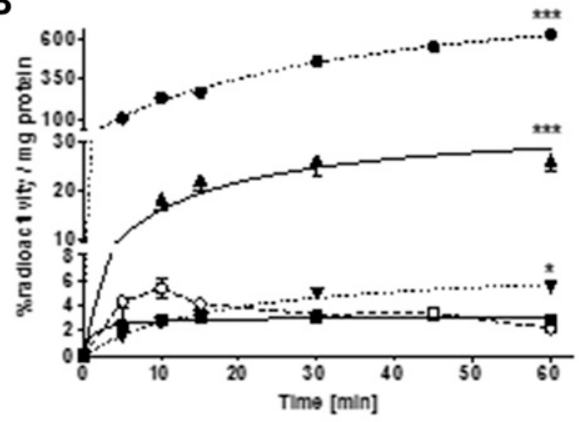

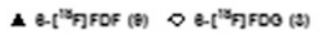

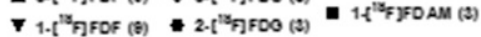

Inhibiting 6-[ $\left.{ }^{18} \mathrm{~F}\right] \mathrm{FDF}$ uptake into human MDA-MB231 cells

D

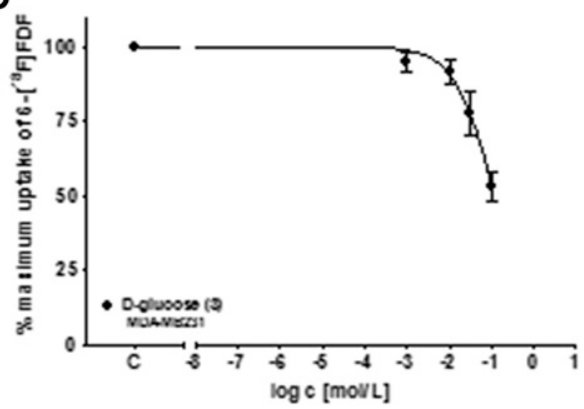

Effect of inhibiting transport through GLUT1, GLUT2, GLUT4

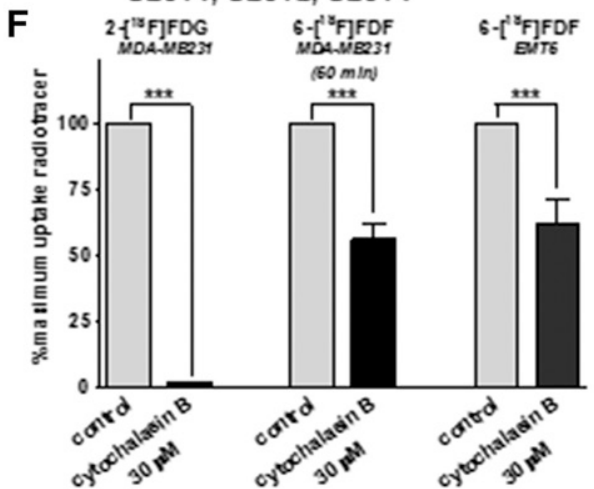

Effect of GLUT5 blocker MSNBA on 6-[ $\left.{ }^{18} \mathrm{~F}\right] \mathrm{FDF}$ transport in murine EMT6 cells

$\mathbf{H}$

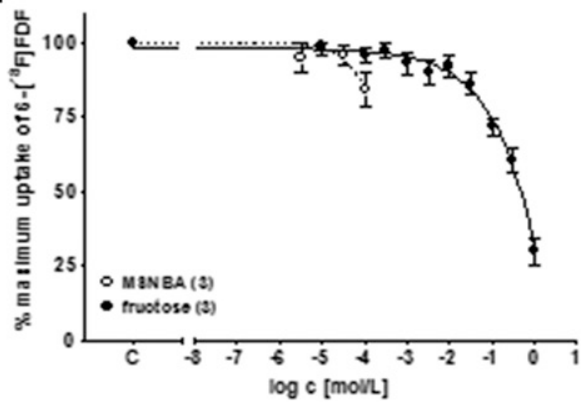

Fig. 2. (A) Inhibition of 6-[ $\left.{ }^{18} \mathrm{~F}\right] \mathrm{FDF}$ uptake into EMT6 cells using nonradiolabeled fructose and 2,5-anhydro-D-mannitol derivatives 1-FDF, 3-FDF, 6-FDF, and 1-FDAM in comparison with fructose. (B) Cellular uptake of radiolabeled glucose, fructose and 2,5-anhydro-D-mannitol derivatives $\left.2-{ }^{18} \mathrm{~F}\right]$ FDG, 6- $\left[{ }^{18} \mathrm{~F}\right] \mathrm{FDG}$ 1- $\left[{ }^{18} \mathrm{~F}\right] \mathrm{FDF}, 6-\left[{ }^{18} \mathrm{~F}\right] \mathrm{FDF}$, and 1- $\left[{ }^{18} \mathrm{~F}\right] \mathrm{FDAM}$ into EMT6 cells over 60 minutes. (C) Inhibitory effect of fructose on 2- $\left[{ }^{18} \mathrm{~F}\right] \mathrm{FDG}$ uptake in EMT6 and MDA-MB231 cells, as well as concentration-dependent inhibition with cytochalasin B (GLUT1, GLUT2, and GLUT4 inhibitor) in MDAMB231 cells in comparison with the effect of glucose on 2- $\left[{ }^{18} \mathrm{~F}\right] \mathrm{FDG}$ in EMT6 cells $\left({ }^{*}\right.$ data from Wuest et al., 2012). (D) Inhibitory effect of glucose on 6- $\left[{ }^{18} \mathrm{~F}\right]$ 
pattern for recognition and transport of radiotracers $1-\left[{ }^{18} \mathrm{~F}\right]$ FDAM, 1- $\left[{ }^{18} \mathrm{~F}\right] \mathrm{FDF}, 6-\left[{ }^{18} \mathrm{~F}\right] \mathrm{FDF}, 2-\left[{ }^{18} \mathrm{~F}\right] \mathrm{FDG}$, and $6-\left[{ }^{18} \mathrm{~F}\right] \mathrm{FDG}$ by hexose transporters GLUT1 and GLUT5. This finding is consistent with recent findings by our group using fluorescent hexose derivatives (Soueidan et al., 2017).

In addition, the cellular uptake of glucose derivative $2-\left[{ }^{18} \mathrm{~F}\right]$ FDG was analyzed in the presence of glucose, fructose, and cytochalasin B (Fig. 2C), as well as the effect of glucose on 6 - $\left[{ }^{18} \mathrm{~F}\right] \mathrm{FDF}$ uptake (Fig. 2D). The $\mathrm{IC}_{50}$ values for fructose against 2- $\left[{ }^{18} \mathrm{~F}\right] \mathrm{FDG}$ uptake revealed $80 \mathrm{mM}$ in EMT6 cells and $210 \mathrm{mM}$ in MDA-MB231 cells, which represents a similar order of magnitude compared with inhibition of $6-\left[{ }^{18} \mathrm{~F}\right] \mathrm{FDF}$ ( $\sim 320 \mathrm{mM}$, see preceding). Glucose had a three orders of magnitude lower $\mathrm{IC}_{50}$ against 6-[ $\left.{ }^{18} \mathrm{~F}\right] \mathrm{FDF}$ : $117 \mathrm{mM}$ (as determined in human MDA-MB231 cells) versus $0.22 \mathrm{mM}$ (measured in murine EMT6 cells) against $2-\left[{ }^{18} \mathrm{~F}\right] \mathrm{FDG}$ uptake. Cellular uptake of both the glucose derivative 2 - $\left[{ }^{18} \mathrm{~F}\right] \mathrm{FDG}$ and the fructose derivative $6-\left[{ }^{18} \mathrm{~F}\right] \mathrm{FDF}$ was slightly higher in murine EMT6 versus human MDA-MB231 BC cells (Fig. 2E) but showed a similar ratio between glucose- and fructosemediated uptake levels. Cytochalasin B $(30 \mu \mathrm{M})$ inhibited $100 \% 2-\left[{ }^{18} \mathrm{~F}\right] \mathrm{FDG}$ uptake but also $~ 50 \%$ of $6-\left[{ }^{18} \mathrm{~F}\right] \mathrm{FDF}$ uptake, indicative for a potential functional involvement of GLUT2 and/or GLUT4 (Fig. 2F). Effects of novel selective GLUT5 inhibitor MSNBA were analyzed against $6-\left[{ }^{18} \mathrm{~F}\right] \mathrm{FDF}$ (Fig. $2 \mathrm{H}$ ) and 2- $\left[{ }^{18}\right.$ F]FDG (Fig. 2G) uptake and compared with the effects of glucose and fructose. MSNBA had only minor inhibition effects using up to $300 \mu \mathrm{M}$ concentration, which was limited by further solubility and DMSO concentration for the cell assay.

Expression Levels of GLUT1 and GLUT5 mRNA in EMT6 Cells, EMT6 Tumors, and Mouse Muscle Tissue. Expression of GLUT1 and GLUT5 mRNA was determined in EMT6 cells, EMT6 tumors, and mouse muscle tissue. In addition, GLUT1 and GLUT5 mRNA levels were compared in tumor and muscle tissue (Fig. 3).

In comparison with GLUT5, mRNA levels of GLUT1 were about 76,000 times higher in EMT6 cells, about 20,000 times higher in EMT6 tumors, and about 45 times higher in muscle tissue. This result indicated that GLUT5 mRNA levels were always significantly lower compared with GLUT1 mRNA levels. In tumor tissue, GLUT1 mRNA levels were about 1.7 times and GLUT5 mRNA levels about 2.4 times higher compared with EMT6 cells. Direct comparison of GLUT1 mRNA levels in tumor and muscle tissue revealed a 60 times higher expression of GLUT1 mRNA in tumor tissue. Unlike to GLUT1 mRNA levels, tumor tissue expressed about six times less GLUT5 mRNA than did muscle tissue.

Protein Expression of GLUT5 in EMT6 Tumors and Muscle Tissue. Western blot analyses of GLUT5 expression in tumor and muscle tissue were performed to correlate determined GLUT5 mRNA levels with GLUT5 protein levels (Fig. 4). Surprisingly and in contrast to the PCR analyses, GLUT5 protein levels were highest in tumor tissue and about $30 \%$ lower in muscle tissues. This finding directs us toward important and significant differences in GLUT5 mRNA and protein levels in tumor and muscle tissue.

Immunohistochemical Determination of GLUT5 in EMT6 Tumors and Muscle Tissue. In addition to Western blot experiments, GLUT5 protein expression levels in tumor and muscle tissue were further analyzed by immunohistochemical staining. Control slides, prepared without antiGLUT5 antibody, revealed no background immunoperoxidase staining and could therefore be used as GLUT5 negative controls. Positive controls were obtained using mouse intestine samples (Fig. 5). Murine duodenum tissue is well known to express high levels of GLUT5 (Fatima et al., 2009).

No staining of GLUT5 protein was detected in the muscle tissue of two individual mice (Fig. 5). Examination of tumor tissue from two mice showed most of the tumor area to be negative for GLUT5 staining, whereas a small region in the center of both tumors showed a high level of GLUT5 staining. This transition from negative to positive staining seemed quite abrupt, and staining frequency increased in tumor regions, where cells appeared to undergo pyknosis. In summary, immunohistochemistry analyses clearly showed GLUT5 protein expression in tumor tissue, whereas muscle tissue was GLUT5-negative.

PET Imaging in EMT6 Tumor-Bearing Mice. PET imaging with ${ }^{18} \mathrm{~F}$-labeled radiotracers $1-\left[{ }^{18} \mathrm{~F}\right] \mathrm{FDAM}, 1-\left[{ }^{18} \mathrm{~F}\right]$ FDF, 6- $\left[{ }^{18} \mathrm{~F}\right] \mathrm{FDF}, 2-\left[{ }^{18} \mathrm{~F}\right] \mathrm{FDG}$, and $6-\left[{ }^{18} \mathrm{~F}\right] \mathrm{FDG}$ in EMT6 tumor-bearing mice revealed important differences in tumor and muscle uptake, as well as in clearance parameters (blood, liver, kidneys, clearance from nontarget tissue muscle).

Figure 6 summarizes all PET images at 15 and 60 minutes postinjection as collected over 2 hours from dynamic PET scans. Tumors were clearly visible after injection of glucose derivative $2-\left[{ }^{18} \mathrm{~F}\right] \mathrm{FDG}$, whereas the other glucose derivative $6-\left[{ }^{18} \mathrm{~F}\right] \mathrm{FDG}$ resulted in much lower tumor uptake levels. Fructose derivative $6-\left[{ }^{18} \mathrm{~F}\right] \mathrm{FDF}$ showed high initial tumor uptake at 15 minutes p.i., followed by a washout of radioactivity from tumor tissue over time; however, the total tumor uptake after 60 minutes of $6-\left[{ }^{18} \mathrm{~F}\right] \mathrm{FDF}$ was markedly lower compared with glucose derivatives $2-\left[{ }^{18} \mathrm{~F}\right] \mathrm{FDG}$ and $6-\left[{ }^{18} \mathrm{~F}\right]$ FDG as seen from the $\mathrm{SUV}_{60 \text { min }}$ values (Fig. 6) but higher than 1- $\left[{ }^{18} \mathrm{~F}\right] \mathrm{FDF}$ and 1- $\left[{ }^{18} \mathrm{~F}\right]$ FDAM. 2,5-Anhydro-D-mannitol derivative 1- $\left[{ }^{18} \mathrm{~F}\right]$ FDAM displayed only low tumor uptake levels with only very little remaining contrast after 60 minutes p.i.. Fructose derivative $1-\left[{ }^{18} \mathrm{~F}\right] \mathrm{FDF}$ showed lowest tumor uptake and image contrast compared with all other tested ${ }^{18} \mathrm{~F}$-labeled radiotracers.

Figure 7 depicts generated TACs for each radiotracer in tumor and muscle tissue over a 2-hour time frame, as well as the corresponding tumor-to-muscle ratios (Fig. 7, bottom right). Radiotracers 2- $\left[{ }^{18} \mathrm{~F}\right] \mathrm{FDG}, 6-\left[{ }^{18} \mathrm{~F}\right] \mathrm{FDG}$ and $6-\left[{ }^{18} \mathrm{~F}\right] \mathrm{FDF}$ showed initial high tumor uptake after 15 minutes p.i. (SUVs $1.01 \pm 0.23(n=4), 1.16 \pm 0.13$ and $1.08 \pm 0.16$, both $n=3)$. As expected, tumor uptake of $2-\left[{ }^{18} \mathrm{~F}\right] \mathrm{FDG}$ continued to increase over time, reaching an $\mathrm{SUV}_{120 \text { min }} 1.97 \pm 0.23(n=4)$, whereas tumor uptake of $6-\left[{ }^{18} \mathrm{~F}\right] \mathrm{FDF}$ decreased constantly to a

FDF uptake in MDA-MB231 cells. (E) Comparison of cellular uptake of 2- $\left[{ }^{18} \mathrm{~F}\right] \mathrm{FDG}$ and $6-\left[{ }^{18} \mathrm{~F}\right] \mathrm{FDF}$ into murine EMT6 and human MDA-MB231 cells after 60 minutes of incubation. (F) Comparison of the inhibitory effect of $30 \mu \mathrm{M}$ cytochalasin B on $2-\left[{ }^{18} \mathrm{~F}\right] \mathrm{FDG}$ and $6-\left[{ }^{18} \mathrm{~F}\right] \mathrm{FDF}$ in MDA-MB231 and EMT6 cells after 60 minutes of incubation. ( $\mathrm{G}$ and $\mathrm{H}$ ) Inhibitory effect of GLUT5 blocker MSNBA on 2- $\left[{ }^{18} \mathrm{~F}\right] \mathrm{FDG}$ (in comparison with glucose) and on 6-[ $\left.{ }^{18} \mathrm{~F}\right] \mathrm{FDF}$ (in comparison with fructose). All data are shown as mean \pm S.E.M. from $n$ experiments. $* P<0.05$; $* * * P<0.001$. 
A
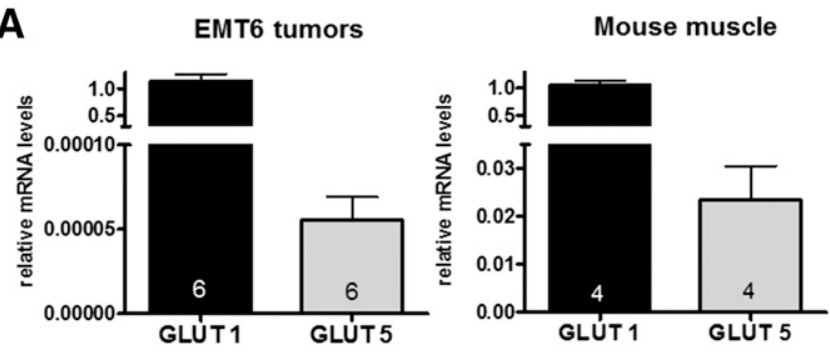

B

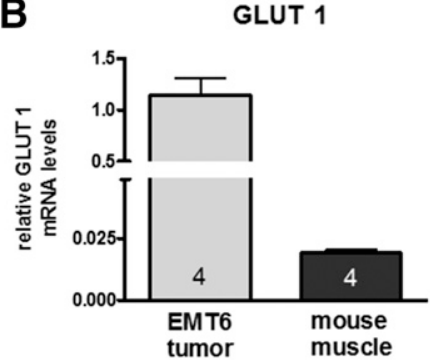

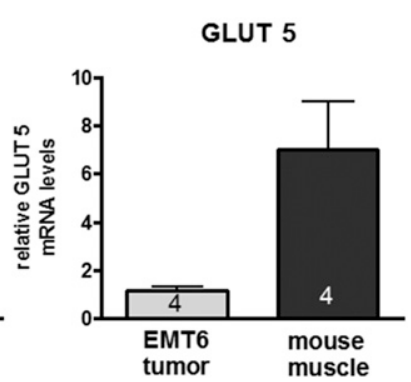

Fig. 3. Relative GLUT mRNA profiles in EMT6 tumor tissue (A, left) and mouse muscle tissue (A, right) and differences in relative GLUT 1 and GLUT 5 mRNA levels between EMT6 tumor tissue and mouse muscle tissue (B, bottom) were determined in reverse transcrioption-polymerase cjain reaction analyses using specific Taqman assays, normalized against 18 S RNA. Data are shown as mean \pm S.E.M. from $n$ experiments.

$\mathrm{SUV}_{120} \min 0.59 \pm 0.06(n=4)$. Tumor uptake of glucose derivative $6-\left[{ }^{18} \mathrm{~F}\right] \mathrm{FDG}$ was lower, peaking at 35 minutes p.i. (SUV $1.28 \pm 0.05$ ) and was slightly reduced over time $\left(\mathrm{SUV}_{120} \min 1.14 \pm 0.05, n=3\right)$. After 2 hours p.i., fructose derivative $6-\left[{ }^{18} \mathrm{~F}\right] \mathrm{FDF}\left(\mathrm{SUV}_{120} \min 0.59 \pm 0.06 ; n=4\right)$ resulted in significantly higher tumor uptake compared $1-\left[{ }^{18} \mathrm{~F}\right] \mathrm{FDF}$ $\left(\mathrm{SUV}_{120} \min 0.31 \pm 0.06 ; n=3 ; P<0.05\right)$ and $1-\left[{ }^{18} \mathrm{~F}\right] \mathrm{FDAM}$ $\left(\mathrm{SUV}_{120}\right.$ min $\left.0.28 \pm 0.01 ; n=3 ; P<0.01\right)$, respectively. Also, uptake of glucose derivative $2-\left[{ }^{18} \mathrm{~F}\right] \mathrm{FDG}\left(\mathrm{SUV}_{120} \min 1.97 \pm\right.$ $0.23 ; n=4)$ was significantly greater than $6-\left[{ }^{18} \mathrm{~F}\right] \mathrm{FDG}$ $\left(\mathrm{SUV}_{120 \text { min }} 1.14 \pm 0.05 ; n=3 ; P<0.05\right)$. A rather unexpected observation was the increasing muscle uptake of $6-\left[{ }^{18} \mathrm{~F}\right] \mathrm{FDG}$ over time since this hexose derivative should not be recognized by hexokinase II and, based on that, would not undergo any intracellular trapping mechanism as shown for the tumor uptake curve. All other radiotracers $\left(1-\left[{ }^{18} \mathrm{~F}\right] \mathrm{FDAM}, 1-\left[{ }^{18} \mathrm{~F}\right]\right.$ FDF, 6- $\left[{ }^{18} \mathrm{~F}\right] \mathrm{FDF}$, and $\left.2-\left[{ }^{18} \mathrm{~F}\right] \mathrm{FDG}\right)$ showed washout from muscle tissue over time. The increasing muscle uptake of 6 - $\left[{ }^{18} \mathrm{~F}\right]$ FDG over time resulted in a decreasing tumor-tomuscle ratio, whereas tumor-to-muscle ratios of other radiotracers increased over time (Fig. 7, bottom right). One-way ANOVA with additional Bonferroni post-test did not reveal any differences in tumor-to-muscle ratios between $1-\left[{ }^{18} \mathrm{~F}\right]$ FDAM, 1-[ $\left[{ }^{18} \mathrm{~F}\right] \mathrm{FDF}, \quad 6-\left[{ }^{18} \mathrm{~F}\right] \mathrm{FDF}$, and $6-\left[{ }^{18} \mathrm{~F}\right] \mathrm{FDG}$; only $2-\left[{ }^{18} \mathrm{~F}\right] \mathrm{FDG}$ had a significantly higher value $(P<0.01)$ after 2 hour p.i.

In contrast to fructose derivative $6-\left[{ }^{18} \mathrm{~F}\right] \mathrm{FDF}$, fructose and 2,5-anhydro-D-mannitol analogs $1-\left[{ }^{18} \mathrm{~F}\right] \mathrm{FDF}$ and $1-\left[{ }^{18} \mathrm{~F}\right]$ FDAM showed only moderate tumor uptake $\left(\mathrm{SUV}_{15} \mathrm{~min}\right.$ $1-\left[{ }^{18} \mathrm{~F}\right]$ FDF $0.47 \pm 0.08$; $1-\left[{ }^{18} \mathrm{~F}\right]$ FDAM $0.58 \pm 0.10$; both $n=3$ ), which decreased over time, reaching $\mathrm{SUV}_{120 \text { min }}$ of $0.31 \pm 0.06$ and $0.28 \pm 0.01$, respectively.

In summary, except for GLUT1 radiotracer $2-\left[{ }^{18} \mathrm{~F}\right] \mathrm{FDG}$, the greatest tumor uptake was observed with fructose analog $6-\left[{ }^{18} \mathrm{~F}\right] \mathrm{FDF}$, whereasa other potential GLUT5 radiotracers

A

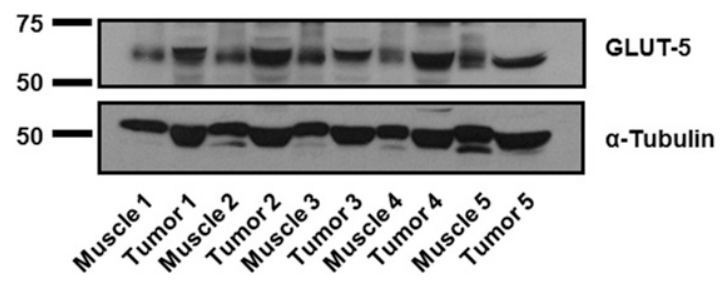

B
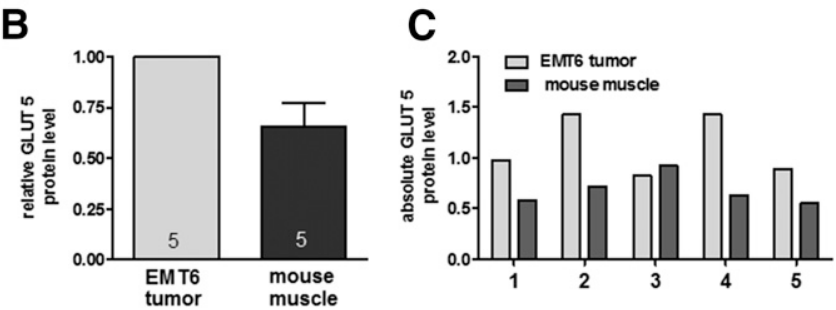

Fig. 4. Quantitative comparison of GLUT 5 protein levels in EMT6 tumor and mouse muscle tissue using Western blot analyses. (A) Western blot analysis; (B) relative GLUT 5 protein analysis normalized to GLUT5 levels in tumor tissue Data are shown as mean \pm S.E.M. from $n$ experiments; (C) absolute data for each animal: comparison of GLUT5 in tumor and muscle tissue.

1- $\left[{ }^{18} \mathrm{~F}\right]$ FDF and 1-[ $\left[{ }^{18} \mathrm{~F}\right]$ FDAM showed much lower tumor uptake levels and only minor differences between specific (tumor) and nonspecific (muscle) uptake.

\section{Discussion}

Glucose analog 2-[ $\left.{ }^{18} \mathrm{~F}\right] \mathrm{FDG}$ is the most versatile and widely used radiotracer for $\mathrm{PET}$ imaging of cancer in the clinic; however, application of $\left[{ }^{18} \mathrm{~F}\right] \mathrm{FDG}-\mathrm{PET}$ in $\mathrm{BC}$ patients has resulted in high nonresponder rates and false-positive responses, which limit the specificity of $\left[{ }^{18} \mathrm{~F}\right] \mathrm{FDG}-\mathrm{PET}$ for BC imaging (Adejolu et al., 2012). Therefore, alternative biomarkers such as estrogen receptors and HER2 have been introduced for more specific targeted molecular imaging of BC (Kenny, 2016; Dalm et al., 2017) being only available at selected and specialized centers and not used routinely.

Shifting from glucose-based to a solely fructose-mediated transport in $\mathrm{BC}$ appeared to be an alternative approach to address specificity concerns of the otherwise $\left[{ }^{18} \mathrm{~F}\right] \mathrm{FDG}-\mathrm{PET}$ dominated clinical practice of $\mathrm{BC}$ imaging. Molecular imaging of fructose transport was first proposed in a study by ZamoraLeón who analyzed fructose transporter GLUT5 expression in BC (Zamora-León et al., 1996). Several subsequent studies described specific targeting of GLUT5 in mammary and human xenograft $\mathrm{BC}$ with various fluorescent or radiolabeled fructose and 2,5-anhydro-D-mannitol derivatives as molecular probes (Levi et al., 2007; Trayner et al., 2009; Wuest et al., 2011; Tanasova et al., 2013; Soueidan et al., 2015, 2017). To date, no systematic and comparative study has been reported on testing various ${ }^{18} \mathrm{~F}$-labeled hexoses and 2,5-anhydromannitols with respect to their GLUT1- and GLUT5-mediated uptake in target (breast tumor) and reference (muscle) tissue. For this purpose, we have selected well-characterized murine mammary gland tumor cell line EMT6 as a suitable preclinical model for this study (Bouvet et al., 2011; Wuest et al., 2011, 2015; Knight et al., 2013; Way et al., 2014).

GLUT1 expression in EMT6 cells has been confirmed by several 2-[ $\left.{ }^{18} \mathrm{~F}\right]$ FDG-PET imaging and cell studies (Rowland 
Mouse intestine

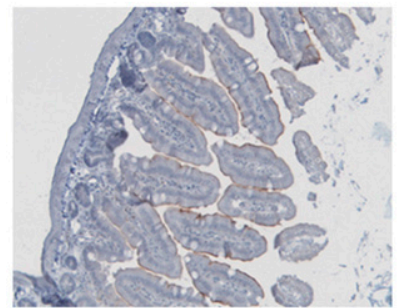

EMT6 tumor 1

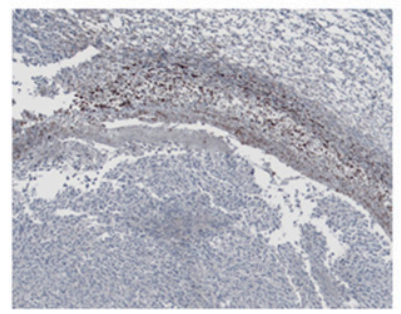

Mouse muscle

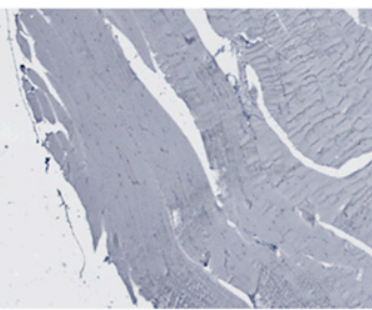

EMT6 tumor 2

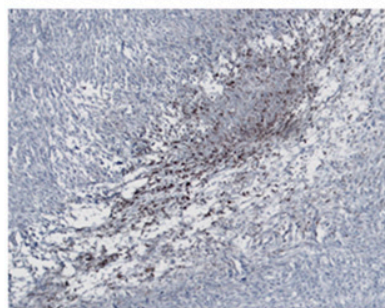

Fig. 5. Immunohistochemical staining of GLUT 5 in mouse intestine (positive control), mouse muscle, and EMT6 tumor tissue. Photos were taken using a $20 \times$ objective.

et al., 2005; Wuest et al., 2011; Kelly et al., 2012). All studies reported high uptake and retention of 2-[ $\left.{ }^{18} \mathrm{~F}\right] \mathrm{FDG}$ in EMT6 cells and tumors consistent with GLUT1-mediated radiotracer uptake and metabolic trapping through phosphorylation by hexokinase II (Wuest et al., 2011). Expression of GLUT5 in BC tissue was reported differently in the literature. Our present results show only low expression of GLUT5 mRNA in EMT6 cells and tumor tissue compared with GLUT1 mRNA levels. GLUT5 mRNA expression was about $6 \times$ greater in muscle versus tumor tissue. This result is contrary to GLUT1 mRNA levels. Subsequent analysis with Western blot revealed elevated GLUT5 protein levels in tumor versus muscle tissue. Immunohistochemistry detected GLUT5 protein in tumor tissue only, probably owing to the limit of detection of this method, using only a thin slice of the tumor tissue compared with Western blot analysis, where much larger parts of the tumor and muscle tissue were analyzed.
GLUT5 protein data provided the basis for the multitracer PET imaging study.

Gowrishankar and coworkers (2011) detected higher GLUT5 mRNA levels in "control" mammary cells MCF10A compared with MCF-7 and MDA-MB 468 cells' however, MCF10A is a nontumorigenic epithelial cell line that has undergone pathophysiological changes, including inflammation (Soule et al., 1990), making this cell line not ideal as a nontumor "control" for BC. Immunohistochemistry from the same study detected no elevated GLUT5 protein in BC versus adjacent normal breast tissue. From 40 BC patients, only $35 \%$ (14 samples) showed staining of $\geq 2$ for GLUT5 protein on a scale from 0 to 4 . Most showed only weak (24 samples) or no (four samples) GLUT5 staining (Gowrishankar et al., 2011), is in contrast to earlier studies demonstrating elevated GLUT5 protein expression levels in BC versus normal breast tissue (Zamora-León et al., 1996; Godoy et al., 2006). Our data on GLUT5 protein expression in murine tumor and muscle tissue supports earlier reports describing elevated GLUT5 protein levels in BC tissue (Zamora-León et al., 1996; Godoy et al., 2006); however, protein levels of GLUT5 in BC tissues remain unclear, and additional studies in different BC patient groups are needed for comprehensive conclusions.

Discrepancy between GLUT5 protein and mRNA expression levels most likely results from complex gene expression biology, which suggests various levels of regulation during protein synthesis (e.g., posttranscriptional, translational, or posttranslational regulation) (Tian et al., 2004). Differential mRNA expression can capture at most $40 \%$ of protein expression variation. Thus, integrated analysis of both mRNA and protein levels is crucial in complex biologic systems like cancer cells. In addition, immunohistochemistry may capture solely skeletal muscle tissue GLUT5 expression at a low level, whereas Western blot analysis using tissue homogenates include a mixture of cells, not just skeletal muscle cells; however, GLUT5 was detected on mRNA as well as protein level concluding for some GLUT5 expression in muscle tissue.

EMT6 cell uptake experiments with all used radiotracers revealed significant uptake of only glucose derivative $2-\left[{ }^{18} \mathrm{~F}\right]$ FDG and fructose analog $6-\left[{ }^{18} \mathrm{~F}\right] \mathrm{FDF}$. Both also showed sufficient uptake in human triple-negative BC cancer
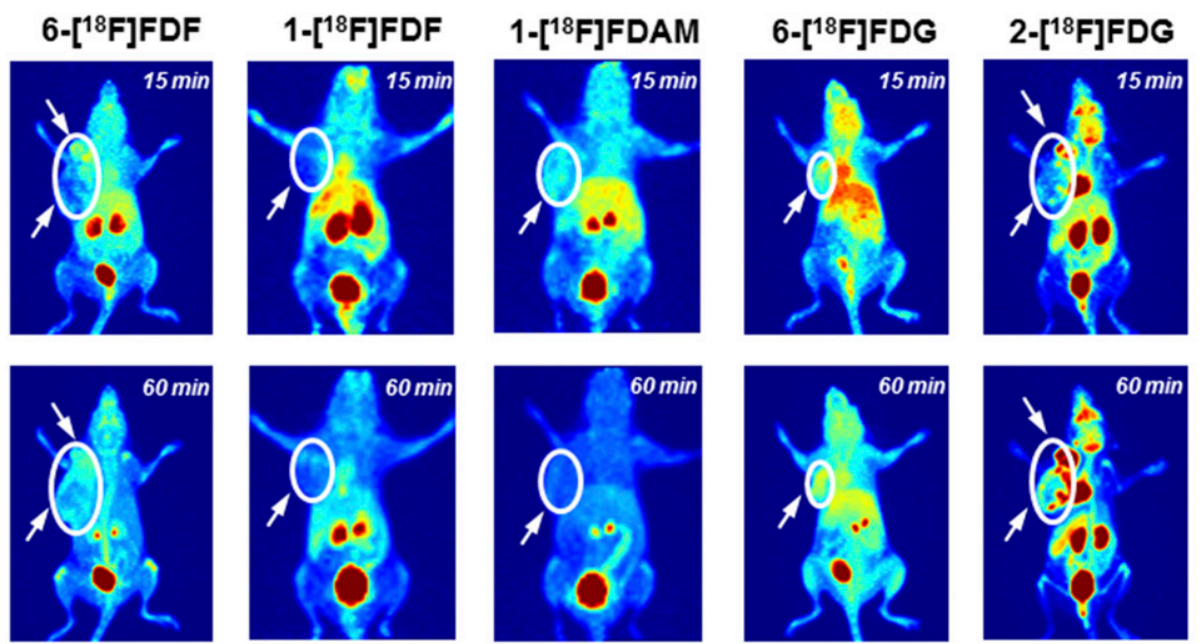

Fig. 6. PET images of $1-\left[{ }^{18} \mathrm{~F}\right] \mathrm{FDF}, 6-\left[{ }^{18} \mathrm{~F}\right]$ FDF, 1-[ $\left[{ }^{18} \mathrm{~F}\right]$ FDAM, 2- $\left[{ }^{18} \mathrm{~F}\right] \mathrm{FDG}$, and $6-\left[{ }^{18} \mathrm{~F}\right]$ FDG after 15 minutes (top) and 60 minutes (bottom) p.i. of 5-7 MBq of the radiotracer into EMT6 tumor-bearing mice. Images are shown as maximum intensity projections (MAP). SUV values at 15 and 60 minutes p.i. are included as mean \pm S.E.M. from $n$ experiments. Tumors are delineated in the images. 


\section{$1-\left[{ }^{18} \mathrm{~F}\right] \mathrm{FDF}$}

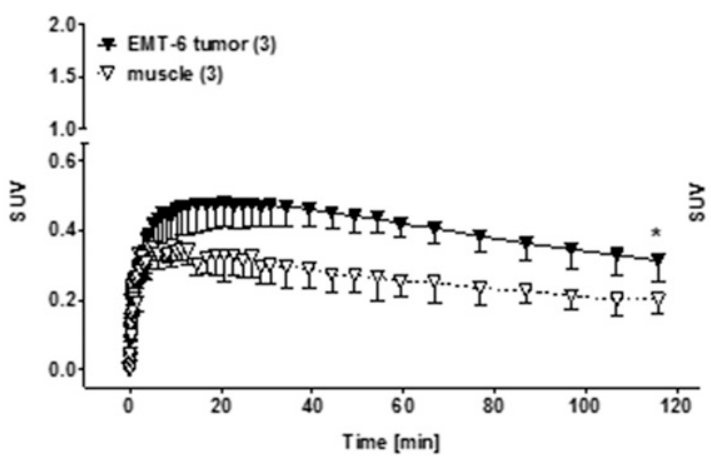

\section{6-[18F]FDF}

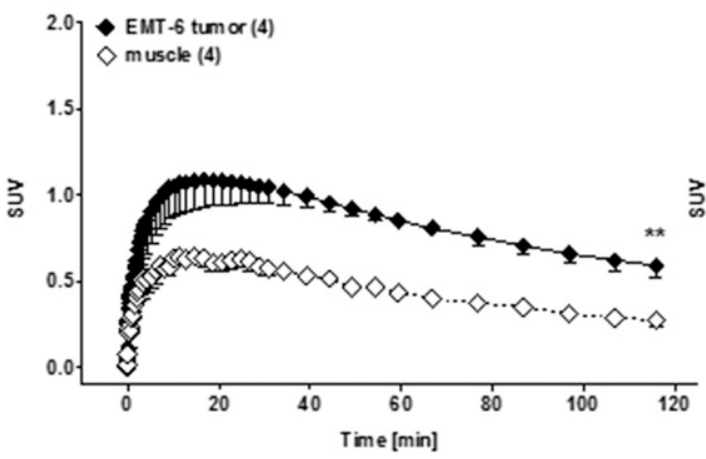

\section{2-[18F]FDG}

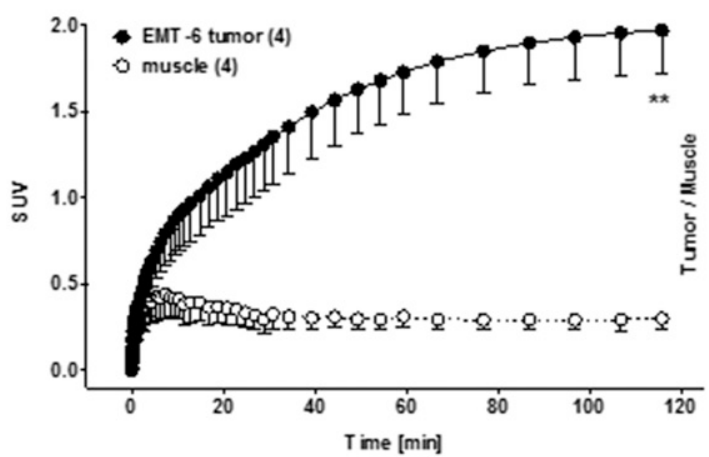

\section{$1-\left[{ }^{18} \mathrm{~F}\right]$ FDAM}

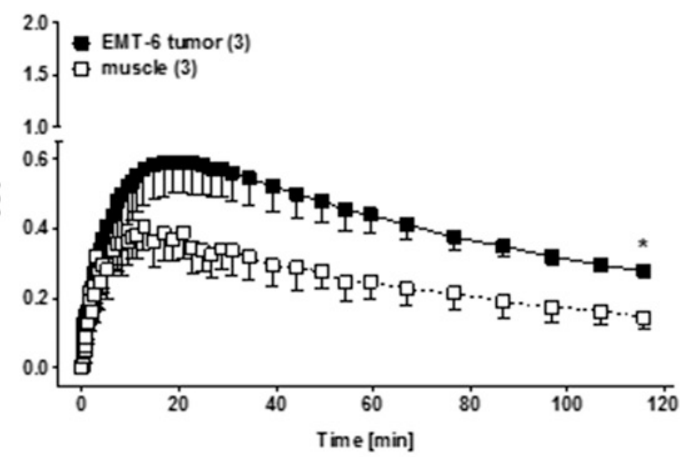

$6-\left[{ }^{18} \mathrm{~F}\right] \mathrm{FDG}$

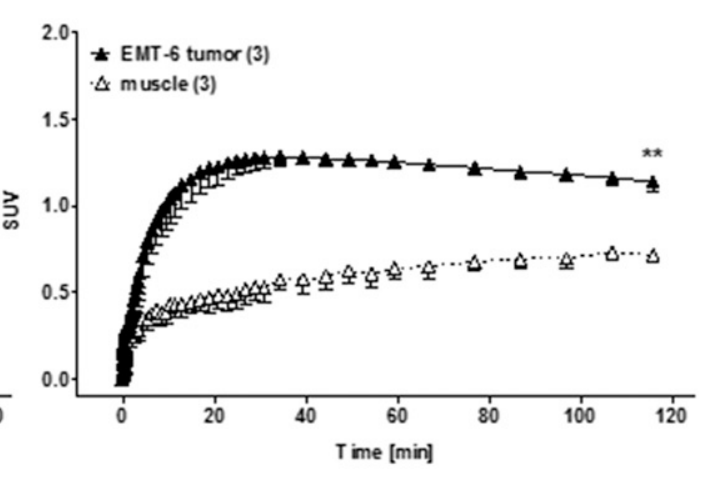

Tumor / Muscle Ratio

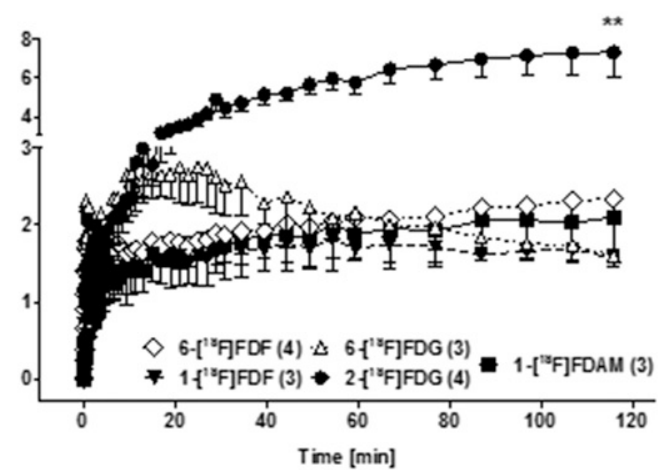

Fig. 7. TACs for EMT6 tumor and muscle tissue uptake profile for 1- $\left[{ }^{18} \mathrm{~F}\right] \mathrm{FDF}, 6-\left[{ }^{18} \mathrm{~F}\right] \mathrm{FDF}, 1-\left[{ }^{18} \mathrm{~F}\right] \mathrm{FDAM}, 2-\left[{ }^{18} \mathrm{~F}\right] \mathrm{FDG}$, and 6- $\left[{ }^{18} \mathrm{~F}\right] \mathrm{FDG}$ over 2 hours p.i. bottom right: TACs for the subsequent calculated tumor-to-muscle ratios for each radiotracer investigated. TACs are presented as semiquantitative SUV and mean \pm S.E.M. from $n$ experiments. ${ }^{*} P<0.05 ;{ }^{* *} P<0.01$.

MDA-MB231 cells, indicating that BC cells with elevated glucose metabolism also have a certain level of elevated fructose consumption. This points toward a similar regulation mechanism of glucose and fructose uptake in both murine and human cells, which would be relevant for the BC patient situation. Uptake of $6-\left[{ }^{18} \mathrm{~F}\right] \mathrm{FDF}$ was not affected in the presence of $5 \mathrm{mM}$ glucose, a concentration, which strongly inhibits glucose transport through GLUT1 (Wuest et al., 2011). At glucose concentrations $>10 \mathrm{mM}$, effects are detected on $6-\left[{ }^{18} \mathrm{~F}\right]$ FDF, which is indicative for involvement of a glucosetransporting GLUT. Incorporation of fluorine in the 6-position also prevented phosphorylation by hexokinase II as demonstrated by cellular efflux owing to a lack of metabolic trapping; however, 6- $\left[{ }^{18} \mathrm{~F}\right] \mathrm{FDF}$ is a substrate of ketohexokinase (Wuest et al., 2011). Evidence has shown that ketohexokinase cannot be detected in numerous cancer cells (Hwa et al., 2006; Trayner et al., 2009; Wuest et al., 2011; Soueidan et al., 2015). Interestingly, fructose derivative $1-\left[{ }^{18} \mathrm{~F}\right] \mathrm{FDF}$, which was reported as a GLUT5 substrate (Haradahira et al., 1995), showed $5 \times$ lower uptake into EMT6 cells compared with structurally related $6-\left[{ }^{18} \mathrm{~F}\right] \mathrm{FDF}$. The presence of the $6-\mathrm{OH}$ group qualifies $1-\left[{ }^{18} \mathrm{~F}\right] \mathrm{FDF}$ as a potential substrate for hexokinase II. Low cell uptake of $1-\left[{ }^{18} \mathrm{~F}\right] \mathrm{FDF}$ versus $6-\left[{ }^{18} \mathrm{~F}\right] \mathrm{FDF}$ is somewhat surprising since both molecules are structural analogs. The only major alteration is the different fluorine-labeling position. As for all hexoses, fructose derivatives $1-\left[{ }^{18} \mathrm{~F}\right] \mathrm{FDF}$ and $6-\left[{ }^{18} \mathrm{~F}\right] \mathrm{FDF}$ can 
form different structural furanose isomers based on the individual substitution pattern of the hexose molecule. Different isomers may exhibit different affinities to GLUT5 and therefore transport properties. On the other hand, cellular uptake of 1- $\left[{ }^{18} \mathrm{~F}\right] \mathrm{FDF}$ was similar to 2,5 -anhydro-D-mannitol derivative 1- $\left[{ }^{18} \mathrm{~F}\right]$ FDAM, a compound with locked furanose-like anomeric conformation. 1-FDAM was developed as an alternative GLUT5 substrate with the potential of intracellular trapping capacity through phosphorylation by hexokinase II (Soueidan et al., 2015). GLUT5-mediated transport of 1- $\left[{ }^{18} \mathrm{~F}\right]$ FDAM was confirmed through inhibition experiments of the radiotracer in the presence of $100 \mathrm{mM}$ D-fructose (Supplemental Fig. 1). Surprisingly both $1-\left[{ }^{18} \mathrm{~F}\right]$ FDAM and $1-\left[{ }^{18} \mathrm{~F}\right] \mathrm{FDF}$ were not substrates of hexokinase II as demonstrated by negative phosphorylation experiments using $2-\left[{ }^{18} \mathrm{~F}\right] \mathrm{FDG}$ as positive control (Supplemental Fig. 1).

Analysis of different transport inhibition effects revealed that fructose itself blocks glucose uptake into murine and human mammary tumor cells, pointing toward functional involvement of other GLUTs beside GLUT5 such as GLUT2. The $\mathrm{IC}_{50}$ for fructose was in a similar concentration range against $6-\left[{ }^{18} \mathrm{~F}\right] \mathrm{FDF}$ uptake $(\sim 320 \mathrm{mM})$ (Wuest et al., 2011$)$ and glucose uptake ( $\sim 80 \mathrm{mM}$ in EMT6 and $\sim 220 \mathrm{mM}$ in MDAMB231 cells). Glucose was also able to interfere with 6 - $\left[{ }^{18} \mathrm{~F}\right]$ FDF transport but with three orders of magnitude higher $\mathrm{IC}_{50}$ ( $\sim 120 \mathrm{mM}$ against 6 - $\left[{ }^{18} \mathrm{~F}\right] \mathrm{FDF}$ vs. $\sim 0.22 \mathrm{mM}$ against glucose). Pointing toward GLUT2 fits well with the reported affinity $\left(K_{\mathrm{i}}\right)$ of glucose $(\sim 17 \mathrm{mM})$ and 2 -FDG $(7 \mathrm{mM})$ for GLUT2 (Sala-Rabanal et al., 2016). Uptake of 2-FDG and 6- $\left[{ }^{18} \mathrm{~F}\right] \mathrm{FDF}$ into murine and human mammary tumor cells was also blocked, pointing toward an additional involvement of another GLUT transporter beside GLUT5. Cytochalasin B is known to inhibit GLUT1-4 but is ineffective to fructose transport through GLUT5 (Chan et al., 2004). Similar observations were reported by Gowrishankar et al. (2011) in human BC MDA-MB468 cells. In addition, we analyzed the effects of a recently described GLUT5 inhibitor MSNBA (George Thompson et al., 2016). Limited by its solubility and the DMSO concentration in the cell assay, $300 \mu \mathrm{M}$ MSNBA only slightly inhibit 6 - $\left[{ }^{18} \mathrm{~F}\right] \mathrm{FDF}$ uptake into murine $\mathrm{BC}$ cells $(\sim 25 \%)$ and also influenced $\left.2-{ }^{18} \mathrm{~F}\right] \mathrm{FDG}$ uptake by $15 \%$. According to George Thompson et al. (2016), $60 \mu \mathrm{M}$ MSNBA should lead to a $50 \%$ inhibition of fructose uptake into human BC MCF7 cells which we did not observe against $6-\left[{ }^{18} \mathrm{~F}\right] \mathrm{FDF}$ in EMT6 cells, indicating that the portion of GLUT5 involvement is quite small. Considering that fact, fructose derivative $1-\left[{ }^{18} \mathrm{~F}\right] \mathrm{FDF}$, as well as anhydro-mannitol 1- $\left.{ }^{18} \mathrm{~F}\right] \mathrm{FDAM}$, shows little EMT6 cell uptake, which corresponds well to preferential GLUT5 transport only.

PET imaging studies of radiotracers $2-\left[{ }^{18} \mathrm{~F}\right] \mathrm{FDG}, 6-\left[{ }^{18} \mathrm{~F}\right]$ FDG, $1-\left[{ }^{18} \mathrm{~F}\right] \mathrm{FDF}, 6-\left[{ }^{18} \mathrm{~F}\right] \mathrm{FDF}$, and $1-\left[{ }^{18} \mathrm{~F}\right] \mathrm{FDAM}$ in EMT6 tumor-bearing mice revealed different uptake patterns in vivo. Glucose derivative $2-\left[{ }^{18} \mathrm{~F}\right] \mathrm{FDG}$ showed highest tumor uptake, including metabolic trapping as typical for $2-\left[{ }^{18} \mathrm{~F}\right]$ FDG as a substrate for GLUT1 and hexokinase II. Lower tumor uptake and no metabolic trapping was observed for $6-\left[{ }^{18} \mathrm{~F}\right] \mathrm{FDG}$ as potential radiotracer for glucose-transport only. Among all radiotracers tested, $1-\left[{ }^{18} \mathrm{~F}\right] \mathrm{FDF}$ and $1-\left[{ }^{18} \mathrm{~F}\right]$ FDAM showed ,the lowest tumor uptake, resulting in overall poor image contrast. Fructose derivative $6-\left[{ }^{18} \mathrm{~F}\right] \mathrm{FDF}$ displayed $2 \times$ higher tumor versus muscle uptake and clearance, leading to better image contrast; however, $1-\left[{ }^{18} \mathrm{~F}\right] \mathrm{FDF}, 6-\left[{ }^{18} \mathrm{~F}\right]$ FDF, and $1-\left[{ }^{18} \mathrm{~F}\right]$ FDAM also showed washout from tumor tissue, confirming no intracellular trapping through phosphorylation with hexokinase II. This is consistent with observed cellular uptake of all three radiotracers into EMT6 cells and negative phosphorylation experiments with hexokinase II (Wuest et al., 2011; Supplemental Fig. 2).

The present data confirm $6-\left[{ }^{18} \mathrm{~F}\right] \mathrm{FDF}$ as a suitable radiotracer for molecular imaging of fructose-mediated metabolism in BC; however, high uptake of $6-\left[{ }^{18} \mathrm{~F}\right] \mathrm{FDF}$ into EMT6 tumors despite rather low expression levels of GLUT5 suggests involvement of additional hexose transporters. Inhibition of $2-\left[{ }^{18} \mathrm{~F}\right] \mathrm{FDG}$ and $6-\left[{ }^{18} \mathrm{~F}\right] \mathrm{FDF}$ uptake into EMT6 cells in the presence of D-fructose suggests functional involvement of GLUT2. GLUT2 as a complementary hexose transporter to GLUT1 (glucose transport only) and GLUT5 (fructose transport only) is involved in both glucose and fructose metabolism. Evidence was reported on a GLUT4 involvement in glucosemediated transport of $2-\left[{ }^{18} \mathrm{~F}\right] \mathrm{FDG}$ into mouse mammary gland cells 5505 while excluding GLUT2 in that specific model (Moadel et al., 2005). Our current results using EMT6 as well as human MDA-MB231 cells point toward GLUT2 considering fructose-mediated transport. Current findings, along with data in the literature on substantial challenge to develop GLUT5-selective molecular probes (Tanasova et al., 2013) and insufficient expression of GLUT5 in human BC tissue (Gowrishankar et al., 2011) point to involvement of additional biomarkers like GLUT2 for targeting fructose-metabolism in $\mathrm{BC}$ and other malignancies.

In conclusion, our results highlight the importance of detailed biochemical studies on GLUT expression levels in combination with PET imaging studies for functional characterization of GLUTs as biomarkers in BC as, for example, involvement of GLUT5 in fructose-mediated transport does not seem to represent the entire picture. Future studies should include experiments to elucidate the detailed functional role of GLUT2 as an additional biomarker for fructose metabolism in BC.

\section{Acknowledgments}

\section{Authorship Contributions}

Participated in research design: M. Wuest, Hamann, Cheeseman, West, F. Wuest.

Conducted experiments: M. Wuest, Hamann, Bouvet, Glubrecht, Marshall, Trayner, Krys.

Contributed new reagents or analytic tools: Bouvet, Soueidan, Wagner.

Performed data analysis: M. Wuest, Hamann, F. Wuest.

Wrote or contributed to the writing of the manuscript: M. Wuest, Hamann, Cheeseman, West, F. Wuest.

\section{References}

Adejolu M, Huo L, Rohren E, Santiago L, and Yang WT (2012) False-positive lesions mimicking breast cancer on FDG PET and PET/CT. AJR Am J Roentgenol 198: W304-W314

Avril N, Menzel M, Dose J, Schelling M, Weber W, Jänicke F, Nathrath W, and Schwaiger M (2001) Glucose metabolism of breast cancer assessed by ${ }^{18} \mathrm{~F}$-FDG PET: histologic and immunohistochemical tissue analysis. J Nucl Med 42:9-16.

Barron CC, Bilan PJ, Tsakiridis T, and Tsiani E (2016) Facilitative glucose transporters: implications for cancer detection, prognosis and treatment. Metabolism 65 : 124-139.

Bouvet V, Jans HS, Wuest M, Soueidan OM, Mercer J, McEwan AJ, West FG, Cheeseman CI, and Wuest F (2014) Automated synthesis and dosimetry of 6deoxy-6-[ $\left.{ }^{18} \mathrm{~F}\right]$ fluoro-D-fructose $\left(6-\left[{ }^{18} \mathrm{~F}\right] \mathrm{FDF}\right)$ : a radiotracer for imaging GLUT5 in breast cancer. Am J Nucl Med Mol Imaging 4:248-259.

Bouvet VR, Wuest M, Wiebe LI, and Wuest F (2011) Synthesis of hypoxia imaging agent 1-(5-deoxy-5-fluoro- $\alpha$-D-arabinofuranosyl)-2-nitroimidazole using microfluidic technology. Nucl Med Biol 38:235-245. 
Brown RS, Leung JY, Fisher SJ, Frey KA, Ethier SP, and Wahl RL (1996) Intratumoral distribution of tritiated-FDG in breast carcinoma: correlation between Glut-1 expression and FDG uptake. J Nucl Med 37:1042-1047.

Chan KK, Chan JY, Chung KK, and Fung KP (2004) Inhibition of cell proliferation in human breast tumor cells by antisense oligonucleotides against facilitative glucose transporter 5. J Cell Biochem 93:1134-1142.

Chudgar AV and Mankoff DA (2017) Molecular imaging and precision medicine in breast cancer. PET Clin 12:39-51.

Dalm SU, Verzijlbergen JF, and De Jong M (2017) Review: receptor targeted nuclear imaging of breast cancer. Int J Mol Sci 18:E260.

Fatima J, Iqbal CW, Houghton SG, Kasparek MS, Duenes JA, Zheng Y, and Sarr MG (2009) Hexose transporter expression and function in mouse small intestine: role of diurnal rhythm. J astroinest Surg 13:634-641.

Gallamini A, Zwarthoed C, and Borra A (2014) Positron Emission Tomography (PET) in oncology. Cancers (Basel) 6:1821-1889.

George Thompson AM, Ursu O, Babkin P, Iancu CV, Whang A, Oprea TI, and Choe JY (2016) Discovery of a specific inhibitor of human GLUT5 by virtual screening and in vitro transport evaluation. Sci Rep 6:24240.

Godoy A, Ulloa V, Rodríguez F, Reinicke K, Yañez AJ, García MdeL, Medina RA, Carrasco M, Barberis S, Castro T, et al. (2006) Differential subcellular distribution of glucose transporters GLUT1-6 and GLUT9 in human cancer: ultrastructural localization of GLUT1 and GLUT5 in breast tumor tissues. J Cell Physiol 207: 614-627

Gowrishankar G, Zitzmann-Kolbe S, Junutula A, Reeves R, Levi J, Srinivasan A, Bruus-Jensen K, Cyr J, Dinkelborg L, and Gambhir SS (2011) GLUT 5 is not overexpressed in breast cancer cells and patient breast cancer tissues. PLoS One 6 e26902.

Haradahira T, Tanaka A, Maeda M, Kanazawa Y, Ichiya YI, and Masuda K (1995) Radiosynthesis, rodent biodistribution, and metabolism of 1-deoxy-1- $\left[{ }^{18} \mathrm{~F}\right]$ fluoro-Dfructose. Nucl Med Biol 22:719-725.

Humbert O, Cochet A, Coudert B, Berriolo-Riedinger A, Kanoun S, Brunotte F, and Fumoleau $\mathrm{P}$ (2015) Role of positron emission tomography for the monitoring of response to therapy in breast cancer. Oncologist 20:94-104.

Hwa JS, Kim HJ, Goo BM, Park HJ, Kim CW, Chung KH, Park HC, Chang SH, Kim YW, Kim DR, et al. (2006) The expression of ketohexokinase is diminished in human clear cell type of renal cell carcinoma. Proteomics 6:1077-1084.

Jadvar H, Alavi A, and Gambhir SS (2009) ${ }^{18}$ F-FDG uptake in lung, breast, and colon cancers: molecular biology correlates and disease characterization. $J$ Nucl Med $\mathbf{5 0}$ $1820-1827$.

Jameson JL and Longo DL (2015) Precision medicine-personalized, problematic, and promising. N Engl J Med 372:2229-2234.

Kelly CJ, Hussien K, and Muschel RJ (2012) 3D tumour spheroids as a model to assess the suitability of [18F]FDG-PET as an early indicator of response to PI3K inhibition. Nucl Med Biol 39:986-992.

Kenny L (2016) The use of novel PET tracers to image breast cancer biologic processes such as proliferation, DNA damage and repair, and angiogenesis. $J \mathrm{Nucl}$ Med 57 (Suppl 1):89S-95S.

Kitajima K and Miyoshi Y (2016) Present and future role of FDG-PET/CT imaging in the management of breast cancer. Jpn J Radiol 34:167-180.

Knight JC, Wuest M, Saad FA, Wang M, Chapman DW, Jans HS, Lapi SE, Kariuki BM, Amoroso AJ, and Wuest F (2013) Synthesis, characterisation and evaluation of a novel copper-64 complex with selective uptake in EMT-6 cells under hypoxic conditions. Dalton Trans 42:12005-12014.

Kurihara H, Shimizu C, Miyakita Y, Yoshida M, Hamada A, Kanayama Y, Yonemori K, Hashimoto J, Tani H, Kodaira M, et al. (2016) Molecular imaging using PET for breast cancer. Breast Cancer 23:24-32.

Kuo SJ, Wu YC, Chen CP, Tseng HS, and Chen DR (2006) Expression of glucose transporter-1 in Taiwanese patients with breast carcinoma-a preliminary report. Kaohsiung J Med Sci 22:339-345.

Laudański P, Koda M, Kozłowski L, Swiatecka J, Wojtukiewicz M, Sulkowski S, and Wołczyński S (2004) Expression of glucose transporter GLUT-1 and estrogen receptors ER-alpha and ER-beta in human breast cancer. Neoplasma 51:164-168.

Lebron L, Greenspan D, and Pandit-Taskar N (2015) PET imaging of breast cancer: role in patient management. PET Clin 10:159-195.

Levi J, Cheng Z, Gheysens O, Patel M, Chan CT, Wang Y, Namavari M, and Gambhir SS (2007) Fluorescent fructose derivatives for imaging breast cancer cells. Bioconjug Chem 18:628-634.

Livak KJ and Schmittgen TD (2001) Analysis of relative gene expression data using real-time quantitative PCR and the 2(-Delta Delta C(T)) method. Methods 25: $402-408$

Macheda ML, Rogers S, and Best JD (2005) Molecular and cellular regulation of glucose transporter (GLUT) proteins in cancer. J Cell Physiol 202:654-662.

Manolescu AR, Witkowska K, Kinnaird A, Cessford T, and Cheeseman C (2007) Facilitated hexose transporters: new perspectives on form and function. Physiology (Bethesda) 22:234-240.
Moadel RM, Weldon RH, Katz EB, Lu P, Mani J, Stahl M, Blaufox MD, Pestell RG, Charron MJ, and Dadachova E (2005) Positherapy: targeted nuclear therapy of breast cancer with 18F-2-deoxy-2-fluoro-D-glucose. Cancer Res 65:698-702.

Neal TR, Schumann WC, Berridge MS, and Landau BR (2005) Synthesis of [18F]-6deoxy-fluoro-D-glucose $\left(\left[{ }^{18} \mathrm{~F}\right] 6 \mathrm{FDG}\right)$, a potential tracer of glucose transport. $J \mathrm{La}$ belled Compd Radiopharm 48:845-854.

Niu B, Wen X, Jia Z, Wu X, Guo W, and Sun H (2013) Synthesis and preliminary evaluation of $1-\left[{ }^{18} \mathrm{~F}\right]$ fluoro-1-deoxy-2,5-anhydro- $D$-mannitol as a PET radiotracer for breast cancer imaging. Chin J Chem 31:1159-1163.

Oude-Munnink TH, Nagengast WB, Brouwers AH, Schröder CP, Hospers GA, Lub-de Hooge MN, van der Wall E, van Diest PJ, and de Vries EG (2009) Molecular imaging of breast cancer. Breast 18 (Suppl 3):S66-S73.

Pfaffl MW (2001) A new mathematical model for relative quantification in real-time RT-PCR. Nucleic Acids Res 29:e45.

Ravazoula P, Batistatou A, Aletra C, Ladopoulos J, Kourounis G, and Tzigounis B (2003) Immunohistochemical expression of glucose transporter Glut1 and cyclin D1 in breast carcinomas with negative lymph nodes. Eur J Gynaecol Oncol 24:544-546.

Rowland DJ, Garbow JR, Laforest R, and Snyder AZ (2005) Registration of [18F]FDG microPET and small-animal MRI. Nucl Med Biol 32:567-572.

Sala-Rabanal M, Hirayama BA, Ghezzi C, Liu J, Huang SC, Kepe V, Koepsell H, Yu A, Powell DR, Thorens B, et al. (2016) Revisiting the physiological roles of SGLTs and GLUTs using positron emission tomography in mice. $J$ Physiol 594:4425-4438. Siegel RL, Miller KD, and Jemal A (2017) Cancer statistics, 2017. CA Cancer J Clin 67:7-30.

Soule HD, Maloney TM, Wolman SR, Peterson WD, Jr, Brenz R, McGrath CM, Russo J, Pauley RJ, Jones RF, and Brooks SC (1990) Isolation and characterization of a spontaneously immortalized human breast epithelial cell line, MCF-10. Cancer Res 50:6075-6086.

Soueidan OM, Scully TW, Kaur J, Panigrahi R, Belovodskiy A, Do V, Matier CD, Lemieux MJ, Wuest F, Cheeseman C, et al. (2017) Fluorescent hexose conjugates establish stringent stereochemical requirement by GLUT5 for recognition and transport of monosaccharides. ACS Chem Biol 12:1087-1094

Soueidan OM, Trayner BJ, Grant TN, Henderson JR, Wuest F, West FG, and Cheeseman CI (2015) New fluorinated fructose analogs as selective probes of the hexose transporter protein GLUT5. Org Biomol Chem 13:6511-6521.

Tanasova M, Plutschack M, Muroski ME, Sturla SJ, Strouse GF, and McQuade DT (2013) Fluorescent THF-based fructose analogue exhibits fructose-dependent uptake. ChemBioChem 14:1263-1270.

Tian Q, Stepaniants SB, Mao M, Weng L, Feetham MC, Doyle MJ, Yi EC, Dai H Thorsson V, Eng J, et al. (2004) Integrated genomic and proteomic analyses of gene expression in Mammalian cells. Mol Cell Proteomics 3:960-969.

Trayner BJ, Grant TN, West FG, and Cheeseman CI (2009) Synthesis and characterization of 6-deoxy-6-fluoro-D-fructose as a potential compound for imaging breast cancer with PET. Bioorg Med Chem 17:5488-5495.

Ulaner GA, Riedl CC, Dickler MN, Jhaveri K, Pandit-Taskar N, and Weber W (2016) Molecular imaging of biomarkers in breast cancer. J Nucl Med 57 (Suppl 1): 53S-59S

Way JD, Wang M, Hamann I, Wuest M, and Wuest F (2014) Synthesis and evaluation of 2-amino-5-(4-[(18)F]fluorophenyl)pent-4-ynoic acid ([(18)F]FPhPA): a novel (18)F-labeled amino acid for oncologic PET imaging. Nucl Med Biol 41:660-669.

Wuest M, Kuchar M, Sharma SK, Richter S, Hamann I, Wang M, Vos L, Mackey JR, Wuest F, and Löser R (2015) Targeting lysyl oxidase for molecular imaging in breast cancer. Breast Cancer Res 17:107.

Wuest M, Kumar P, Wang M, Yang J, Jans HS, and Wiebe LI (2012) In vitro and in vivo evaluation of [(18)F]F-GAZ, a novel oxygen-mimetic azomycin-glucose conjugate, for imaging hypoxic tumor. Cancer Biother Radiopharm 27:473-480.

Wuest M, Trayner BJ, Grant TN, Jans HS, Mercer JR, Murray D, West FG, McEwan AJ, Wuest F, and Cheeseman CI (2011) Radiopharmacological evaluation of 6-deoxy-6- $\left[{ }^{18} \mathrm{~F}\right]$ fluoro-D-fructose as a radiotracer for PET imaging of GLUT5 in breast cancer. Nucl Med Biol 38:461-475.

Yamamoto T, Seino Y, Fukumoto H, Koh G, Yano H, Inagaki N, Yamada Y, Inoue K, Manabe T, and Imura H (1990) Over-expression of facilitative glucose transporter genes in human cancer. Biochem Biophys Res Commun 170:223-230.

Younes M, Brown RW, Mody DR, Fernandez L, and Laucirica R (1995) GLUT1 expression in human breast carcinoma: correlation with known prognostic markers. Anticancer Res 15 (6B):2895-2898.

Zamora-León SP, Golde DW, Concha II, Rivas CI, Delgado-López F, Baselga J, Nualart F, and Vera JC (1996) Expression of the fructose transporter GLUT5 in human breast cancer. Proc Natl Acad Sci USA 93:1847-1852.

Address correspondence to: Melinda Wuest, Department of Oncology, University of Alberta, 11560 University Avenue, Edmonton, AB T6G 1Z2, Canada. E-mail: mwuest@ualberta.ca 